\title{
"A La Ursa quer dinheiro, quem não dá é pirangueiro": transformações no carnaval das La Ursas em São Caitano ${ }^{1}(\mathrm{PE})^{2}$
}

"A La Ursa quer dinheiro, quem não dá é pirangueiro": changes in the carnival of La Ursas in São Caitano-PE

Marilia Santos ${ }^{3}$ Universidade Federal de Pernambuco (UFPE) marilia_05030@hotmail.com 


\section{Resumo}

A La Ursa é uma brincadeira carnavalesca do Nordeste do Brasil. O personagem principal é um Urso. É comum encontrar essa expressão no estado de Pernambuco. Com as diversas mudanças na sociedade, a La Ursa também se transformou, incluindo seu som e sua música. Este artigo tem como objetivo descrever e discutir a história da La Ursa em São Caitano (PE), apontando para as transformações da brincadeira durante o carnaval na cidade. Foram realizadas entrevistas com o presidente da Associação das La Ursas de São Caitano e com outras pessoas envolvidas com a história e com as modificações da brincadeira. As mudanças necessárias para garantir a existência da La Ursa estão ligadas, sobretudo, a fatores econômicos, políticos e culturais.

Palavras-chave: La Ursa. São Caitano. Carnaval. Música e Som. Etnomusicologia.

\section{Abstract}

La Ursa is a carnival play in the Northeast of Brazil. The main character is the Urso (Bear). It is common to find this expression in the state of Pernambuco. Within the many changes in society, La Ursa has also changed, including its sonorities and its music. This paper aims to describe and discuss the history of La Ursa in São Caitano-PE, focusing on the transformations of the play in the context of the carnival. We have conducted interviews with the president of the Association of La Ursas of São Caitano and other people involved with in the history and the changes of the play. The transformations necessary to ensure the existence of the La Ursa are mainly binded to economic, political, and cultural factors.

Keywords: La Ursa. São Caitano. Carnival. Music and Sound. Ethnomusicology.

1 De acordo com o site do IBGE, este município é grafado com "i". Ao realizar citações que têm a grafia com "e", manteremos a ortografia da fonte. Inclusive as gestões (atual e anteriores) do município, assim como muitos(as) professores(as) e outras pessoas, têm escrito o nome de forma equivocada, com "e", e não da maneira como ele está registrado, com "i". Paraná.

2 Agradeço às pessoas entrevistadas: John Garçom, presidente da Associação das La Ursas de São Caitano; Rodrigo Novaes, secretário de Turismo de Pernambuco; Mariza Santos, professora da rede municipal de ensino de São Caitano; Ênio Quirino, enfermeiro e vereador de São Caitano; Marliete, diretora, produtora, tesoureira e estilista do Urso da Rua do Sapo; Gleybinho, um dos responsáveis pela organização da música do Urso da Rua do Sapo; Maria de Lourenço, pessoa que recebia as La Ursas em sua casa; e Xoba, pessoa que tem mantido a tradição da La Ursa em São Caitano durante os últimos cinquenta anos. Agradeço também ao músico e etnomusicólogo Lucas Oliveira de Moura Arruda, por ter feito duas transcrições que estão presentes neste texto. Agradeço ainda ao editor da revista Orfeu, Guilherme Sauerbronn, e aos avaliadores (ou avaliadoras), que deram importantes contribuições para a revisão e finalização deste artigo.

3 Musicista e poetisa. Professora substituta no Departamento de Música da Universidade Federal de Pernambuco. Mestra em Música, com área de concentração em Etnomusicologia. Graduada em Música e em Letras. Outros meios de contato: marilia.503031@gmail.com e @mar_ilha.marilia. 


\section{Introdução}

A La Ursa ${ }^{4}$ é uma brincadeira ${ }^{5}$ do Nordeste do Brasil que tem como personagem principal um Urso. Ao lado de manifestações que the deram origem, presentes no país desde a época do Brasil Colônia, ela tornou-se uma folia carnavalesca bastante significativa durante o século XX. É possível observar que durante décadas a brincadeira mantevepadrões semelhantes nos diferentes lugares em que acontecia. Com o passar do tempo, a La Ursa foi se modificando. Neste artigo busco descrever e discutir a história da La Ursa na cidade de São Caitano (PE), apontando para as transformações da brincadeira durante o carnaval nessa cidade. Ela acontece durante o carnaval e nas semanas que o antecedem.

Quando eu era criança, esperava ansiosa pela passagem das La Ursas na rua onde eu morava. O que eu sentia era uma mistura de medo e encantamento por aquele "animal" grande, colorido, brilhante, luxuoso. Meu coração batia forte ao ouvir as batucadas que soavam enquanto a La Ursa se aproximava da minha casa. Apesar do medo, quase todas as vezes eu esperava o "bicho", na porta de casa, com uma moeda ou outro agrado. Lembro-me de ficar debruçada na janela olhando as La Ursas que paravam para festejar com a vizinha do lado.

Para essa investigação realizei pesquisa de campo, incluindo, inclusive, a minha própria vivência, pois cresci vendo as La Ursas durante o carnaval. Fiz entrevistas com o presidente da Associação das La Ursas de São Caitano e com outras pessoas que puderam contar um pouco sobre o Concurso das La Ursas, a história da brincadeira e da cidade, que se faz importante para entender o contexto no qual o folguedo está inserido. As histórias, com base na memória de várias pessoas, dão alicerce para a compreensão de como está ocorrendo a mudança da La Ursa em São Caitano e dos motivos para essa mudança. Além disso, esse registro das La Ursas de São Caitano pode apontar para a importância em salvaguardar o patrimônio cultural imaterial brasileiro.

O texto está dividido em duas partes. A primeira aborda as possíveis origens da La Ursa. Aponto as hipóteses da chegada de manifestações que deram início à brincadeira e falo sobre a La Ursa em Pernambuco. A segunda parte se dedica à La Ursa na cidade de São Caitano, sua história, transformações, o surgimento do desfile das La Ursas e, anos depois, do concurso das mesmas. Abordo a música (o som) que constitui a brincadeira, assim como o processo que levou São Caitano a ser oficializada, entre 2019 e 2020, a cidade das La Ursas, o que parece, entre outras coisas, uma tentativa de criar uma identidade local e de elevar a valorização da brincadeira, a partir de interesses políticos, econômicos e culturais.

\footnotetext{
4 La Ursa é o nome da brincadeira. Mas também é o nome utilizado para se referir ao personagem principal: o Urso. Logo, La Ursa e Urso também são usados pelas pessoas como sinônimos. Quando falamos La Ursas, no plural, estamos nos referindo aos vários grupos de La Ursas, ou aos vários Ursos.

5 Folguedo, folia. Brincadeira e folguedo estão mais relacionados às manifestações festivas das culturas populares que têm um caráter tradicional. Algumas pessoas definem folguedo como as brincadeiras que têm relações com alguma religião. Neste texto optamos em utilizar "brincadeira" e "folguedo" como sinônimos. Devemos mencionar que nenhuma das pessoas entrevistadas fala em "brincadeira" e "brincantes". Folia está mais relacionada à diversão em geral, estando presente nas brincadeiras e em outros festejos também.
} 


\section{La Ursa}

\section{Culturas "estrangeiras", brincadeira(s) brasileira(s)}

Acredita-se que tudo teve início na Europa, quando povos ciganos exibiam animais selvagens, obrigando-os a "dançar" em troca de moedas. Era comum que dissessem: "Dança, La Ursa!". Especula-se que os povos que trouxeram tais costumes para o Brasil tinham algum tipo de ligação com a arte do circo, pois apresentavam um número, com animais, denominado "amestrados". Essas culturas chegaram ao Brasil ainda na época da colônia, com trabalhadores que emigraram da Itália. Existe uma versão que diz que a tradição surgiu a partir do filho do marechal Floriano Peixoto, que brincava com ursos (REAL, 1967, p.122-130; ARANHA, 2015, p.122; ALVES, 2017; ESTEVES, 2018; LIMA, 2019; URSOS..., 2020). Katarina Real confirma, no texto "A 'La Ursa': os Ursos de carnaval do Recife" (1967), a origem da brincadeira a partir dos povos italianos.

Ovídio da Cunha explica, no texto "Ursos e maracatús", que é provável que italianos bons na metalurgia de cobre tenham trabalhado nos engenhos de Pernambuco durante o período colonial. O autor aponta que "dessa pequena população de artífices teriam surgido os 'ursos', sociedades filiadas à 'Federação Carnavalesca', que aparecem conduzindo um urso acorrentado pelo focinho, sendo dirigido por um homem de bigodes compridos". Cunha também coloca que havia um grupo de moças com pandeiros, porém a predominância era de instrumentos de cordas (CUNHA, 1948, n.p.).

Sobre a história do filho do segundo presidente do Brasil, Floriano Peixoto, que tinha o nome igual ao do seu pai, Real escreve que, numa pesquisa de campo, Seu João da Malária contou-lhe a seguinte história: um dia, o filho do presidente, que era lutador, estava tomando cachaça quando um italiano passou com um urso. Então Floriano Peixoto (filho) disse: "Eu vou lutar com aquêle urso". A autora chama a atenção para a "folclorização dum acontecimento histórico" e afirma ainda o fato de não existirem evidências que apontem isso como a origem do urso de carnaval (REAL, 1967, p.124).

Segundo Benjamin, a La Ursa era um cortejo constituído por um folgazão ${ }^{6}$ mascarado e vestido com estopas. Uma outra pessoa, que interpretava o caçador ou taliano, ${ }^{7}$ o segurava por uma corda presa à cintura. Um grupo de meninas os acompanhava. É provável que a La Ursa seja uma entremez do Bumba meu boi (BENJAMIN, 1989, p.94). Esteves (2018) explica que é possível que tenha havido também misturas com os caboclinhos e com outras formas de manifestações.

Outras fontes indicam que a brincadeira teve início com um homem, ou uma muIher mais velha, fantasiado(a) com um macacão e uma máscara, normalmente de papel machê, e o domador, que usava um chapéu utilizado para arrecadar o dinheiro (Fig. 1) (ALVES, 2017; ESTEVES, 2018; A LA URSA..., 2019; LIMA, 2019). Nenhuma dessas fontes indica o período exato em que a brincadeira, como ficou conhecida na segunda meta-

6 Brincante, folião. Brincante e folgazão são as pessoas que estão envolvidas com a constituição da brincadeira, seus participantes. Folião é mais geral. É quem participa de folias e festas.

7 Provavelmente o italiano. 
de do século $X X$, principalmente, teve início. Real explica que o domador também era chamado de italiano ou comandante e que às vezes alguns Ursos tinham um terceiro personagem, o caçador, que fingia dar tiros com uma espingarda quando o Urso interpretava uma tentativa de fuga (REAL, 1967, p.122).

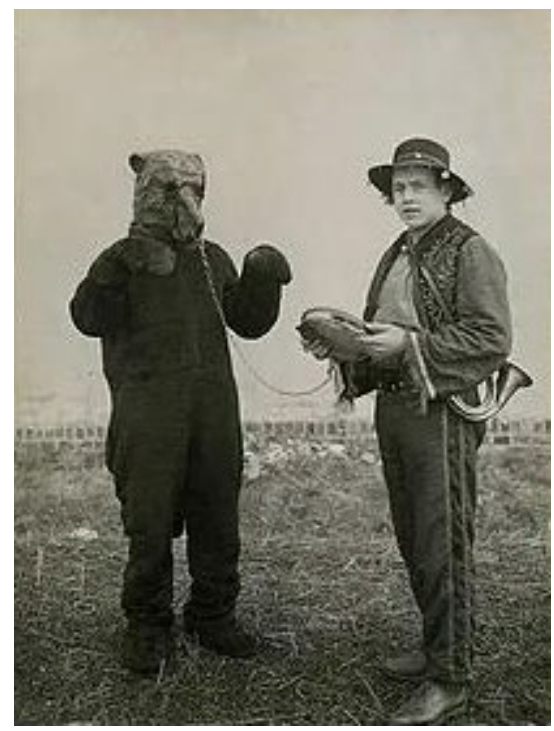

Fig. 1: A La Ursa e o domador. Não há indicações no site do ano ou do local dessa fotografia.

Fotografia: Acervo Fundaj. Fonte: Esteves (2018). ${ }^{8}$

Alves (2017) explica que um grupo de crianças acompanhava os personagens, batendo em baldes, para incomodar as pessoas e fazê-las contribuir com alguma quantia. Diferentemente de Benjamin (1989), que diz que o grupo era formado por meninas, Alves não especifica o sexo das crianças. A Fig. 1, por exemplo, mostra o domador com uma espécie de trompa embaixo de um dos braços e talvez um pandeiro nas mãos, sem crianças ou outros acompanhantes.

Personagens e instrumentação foram ficando mais diversificados, a banda passou a ter diferentes instrumentos e a tocar ritmos como xote, polca e baião (LIMA, 2019). Mas isso não aconteceu no mesmo período em todos os lugares. Em São Caitano, a diversificação dos instrumentos ainda é pouca. A maior parte dos grupos de La Ursa dessa cidade continua utilizando somente instrumentos de percussão.

O Urso se popularizou porque o animal passou a fazer parte do imaginário popular. Em outros lugares há registro da utilização dele para alimentação, vestimenta, religião, mitologia, peças teatrais, canções, literatura (A LA URSA..., 2019). Entretanto, nenhuma parte do Brasil é habitat desse animal. Essa imagem já chegou em terras brasileiras por meio de culturas estrangeiras e foi se hibridizando com os diversos elementos e povos (Fig. 2).

8 Algumas figuras, como esta, por exemplo, não estão com uma qualidade boa. Algumas delas são de prints feitos por nós das páginas da internet. Nem sempre há a opção de fazer download. Muitas delas já não estavam com boa qualidade nos sites e redes sociais, porém não conseguimos outras com qualidade melhor e, entendendo que elas são importantes para a compreensão da história e da brincadeira da La Ursa, decidimos mantê-las no texto. 


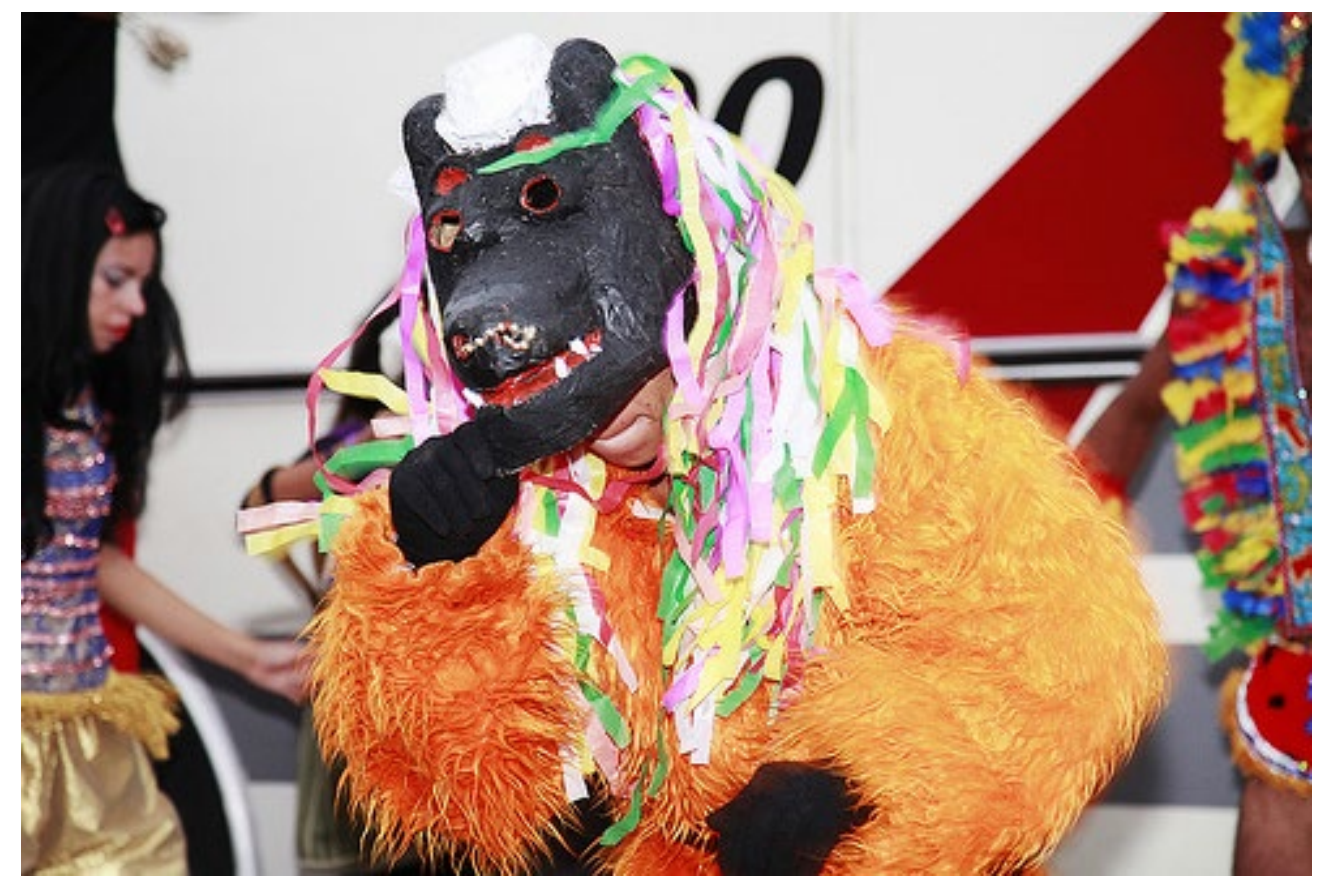

Figura 2: La Ursa no estilo de São Caitano na década de 1990. Fonte: Carnaval de Recife e Olinda (2019).

Quando, em entrevista, perguntamos ao Xoba (Luiz Antônio Henrique dos Santos), o brincante ativo mais antigo de La Ursa em São Caitano, qual o significado do Urso, ele respondeu: "Significa gaia!" (XOBA, 2021). Na cultura local, a palavra "gaia" é sinônimo de "chifre", traição. Nesse imaginário popular do urso, está muitas vezes relacionado com a figura do amante. Porém, nem todas as pessoas enxergam o personagem desse jeito. Maria de Lourenço (a minha vizinha que recebia as La Ursas em casa), também entrevistada por nós, explicou que para ela os Ursos significam a alegria do carnaval (MARIA DE LOURENÇO, 2021).

De acordo com Real (1967, p.124), há registros de cultos ao urso na Europa que datam da Idade da Pedra. A autora relata que os apontamentos da antropologia mostram que nesses cultos, há dez mil anos antes de Cristo, caçadores se vestiam com peles e caveiras de ursos e dançavam. Esses rituais normalmente aconteciam no período de inverno, quando nesses lugares tornava-se mais difícil encontrar comida e sobreviver. Os ursos também eram pintados nos tetos e nas paredes das cavernas onde esses caçadores habitavam. A autora continua explicando que, milênios depois, duas constelações receberam o nome de ursas: a maior e a menor.

Porém, ainda segundo Real (1967, p.124), é na Idade Média que está o ancestral mais próximo do Urso de carnaval. A autora esclarece que "documentos e desenhos dos séculos $\mathrm{XI}$ até $\mathrm{XV}$ " apontam para a existência de ursos em feiras e vilas em festivais na Europa. O animal era utilizado como uma espécie de atração, sendo conduzido por menestréis e jongleurs. Normalmente estes, ou algum palhaço, lutavam contra os ursos. Muitas vezes os jongleurs e os palhaços preferiam enfrentar um outro homem vestido de urso em vez do animal de verdade. Também era comum existirem outros animais, como leões, camelos e macacos, mas o mais frequente era o urso. O domador também costumava colocar cachorros para irritar o urso e chamar a atenção das pessoas. 
Segundo Aranha (2015, p.124-125), alguns lugares, como João Pessoa (PB), têm a La Ursa representada também por um macaco. E lá se diz o La Ursa, no masculino. Apesar de em João Pessoa existirem alguns grupos de La Ursas que têm um macaco como o personagem principal, o Urso parece ser ainda, na maioria dos lugares onde a brincadeira acontece, a figura central.

Embora existam várias hipóteses sobre o surgimento da La Ursa, percebemos que é comum encontrar uma relação com os povos italianos e com os ciganos que viviam na Itália e que emigraram para o Brasil. Além disso, também existe a ênfase constante de que essas culturas tinham meios de ganhar dinheiro através de animais, sobretudo os selvagens. Para Real (1967, p.129-130), não há dúvidas de que o Urso de carnaval veio da Itália. Em 1961, no bairro de Afogados, em Recife, a agremiação do Urso Aliado cantou alguns versos para a antropóloga. O primeiro quarteto diz o seguinte:

\author{
Viemos da Itália \\ Não trouxemos roupa \\ Trouxemos êste Urso \\ Enrolado na estôpa. \\ (REAL, 1967, p.130).
}

Embora não saibamos com precisão quando e onde a brincadeira surgiu, podemos afirmar que no Nordeste. Apesar das diferenças que são encontradas em cada cidade, ela se constituía, sobretudo, por grupos de pessoas de classes econômicas baixas, e o folguedo tinha um Urso como personagem principal: a La Ursa, que atuava como um animal feroz, selvagem. Além disso, há em comum o fato de a La Ursa sempre pedir dinheiro ou algum outro "agrado". Xoba confirma essa afirmação, explicando que foram as pessoas pobres que criaram e mantiveram a La Ursa em São Caitano, por exemplo (XOBA, 2021). Pedir algo está relacionado com a própria suposta origem da brincadeira, como também com o pouco poder econômico dos(as) brincantes das La Ursas.

Em Minas Gerais - na região Sudeste do Brasil -, há o Bloco do Urso (BLOCO DO URSO, 2020). Segundo as informações disponíveis no site, essa manifestação não aparenta ter relação com a brincadeira La Ursa que acontece no Nordeste.

\title{
A La Ursa em Pernambuco
}

Imagine a cena: você está em casa, de repente ela é invadida por um "urso" feroz, [...] um grupo enorme de crianças e jovens batucam baldes e panelas o refrão: "A La Ursa quer dinheiro, quem não dá é pirangueiro...". Quem viveu nas periferias do Recife [Capital de Pernambuco] nas décadas de 1980 e 1990 certamente viu ou viveu cenas parecidas a estas. (ALVES, 2017).

O registro mais antigo da La Ursa em Pernambuco é de Pereira Costa, no livro Folclore Pernambucano, que reproduz o relato do francês Tollerane, que fala sobre uma manifestação com um Urso no pátio de uma igreja do Recife em 1817 (REAL, 1967, p.126; ESTEVES, 2018). Real (1967, p.126) explica que a dança realizada pelo Urso "está incluída por Pereira da Costa entre as 'danças africanas lascivas'". A performance era realizada 
por um homem (macho) e uma mulher (fêmea), numa espécie de dança sensual. Nesse contexto, continua Real (1967, p.126), o caçador afugentava os(as) espectadores(as), sobretudo as moças.

Esse registro nos remete novamente ao imaginário popular que coloca o Urso como um amante. Nesse sentido, não somente o amante na acepção da traição, mas daquele que ama. Também podemos pensar na questão sexual como algo "animalesco". A canção Como dois animais, de um dos principais ícones do carnaval de Pernambuco, Alceu Valença, descreve um pouco essa situação presenciada e relatada por Tollerane. Mas, nesse caso, o cantor e compositor optou por usar uma onça e um cão (um cachorro), em vez de um urso. Vejamos o trecho final da música.

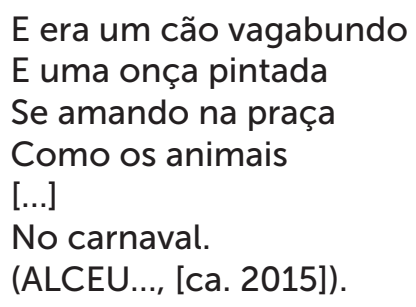

Real (1967, p.125) relata que em suas pesquisas teve conhecimento, por meio dos irmãos Valença e Valdemar de Oliveira, da existência de uma polca que era bastante popular no Recife no início do século XX: Olha o Urso. Atualmente vemos a La Ursa aparecer de várias formas nas canções que nascem em Recife, como, por exemplo, a música Ladeira do fim do mundo, do músico e professor Sérgio Gaia. Em nenhum momento a La Ursa é citada na letra. Porém, no videoclipe, a La Ursa toma conta da cena, com vários "gestos" que remetem aos carnavais do Recife e de Olinda, à cultura de descendência afro e, na concepção do vídeo, com referências dos clipes das músicas Paradise e The scientist, da banda britânica Coldplay (Fig. 3). 


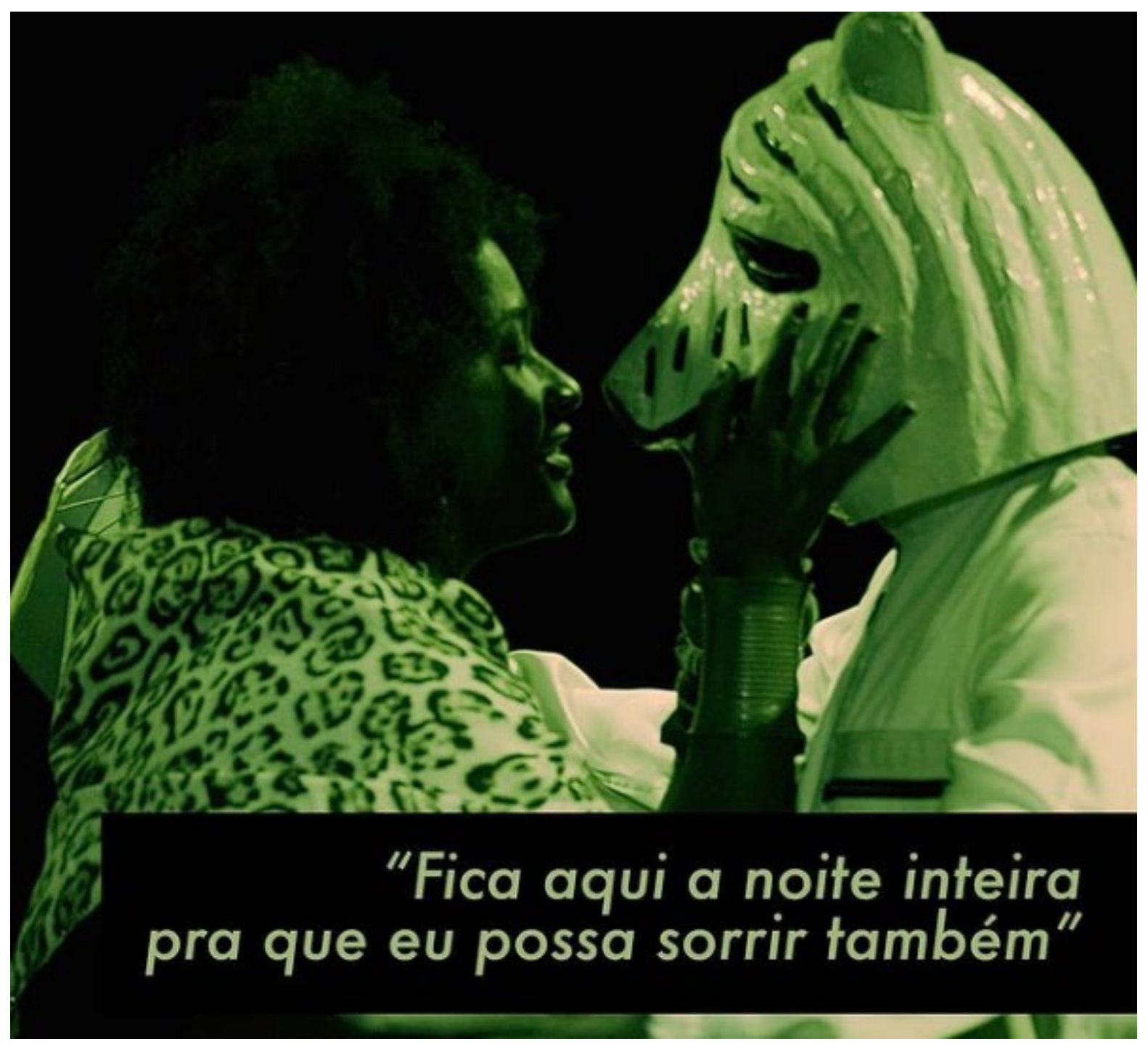

Fig. 3: Imagem da divulgação do lançamento do videoclipe de Ladeira do fim do mundo. Fonte: (GAIA, 2021).

Real (1967, p.123-124) assinala que, nas orquestras de Ursos mais elaboradas, havia uma diversidade de instrumentos, como cavaquinho, violão, surdo tarol, clarinete, trombone, charanga, triângulo, bombo, reco-reco, pandeiro, tamborim e o instrumento que não poderia faltar: a sanfona. Porém o que se tornou muito comum nas últimas décadas, pelo menos na região agreste de Pernambuco, foram os grupos de La Ursas com instrumentos de percussão, somente.

Acreditamos que isso ocorre pela facilidade em obter e confeccionar esses instrumentos, assim como pelo fato de objetos cotidianos - como latas, caixas de papelão, baldes - poderem ser utilizados com a finalidade de produzir som para a brincadeira da La Ursa. Esteves (2018), por exemplo, ao falar da La Ursa em Recife, explica que as batucadas eram realizadas em latas de tinta. Segundo ele, a brincadeira tem passado por uma perda de memória afetiva e se elitizado. Porém, é possível encontrar grupos que se reúnem, mantendo os costumes mais antigos. Em Recife, algumas pessoas acreditam que a brincadeira diminuiu por conta da violência e do crime (ESTEVES, 2018). 
Em entrevista para Esteves, o historiador Mário Ribeiro explica que a brincadeira da La Ursa "perdeu espaço para um novo modelo de brincar Carnaval no Recife". Ribeiro ainda conta que o novo modelo de carnaval, com a "cultura dos camarotes", também tem contribuído para o desaparecimento dos carnavais de bairro (RIBEIRO apud ESTEVES, 2018). Ele explica que

\begin{abstract}
As práticas culturais são vivas e se modificam de acordo com as necessidades dos grupos que fazem parte e dão sentido de existência àquela prática. Vários fatores contribuíram para a menor intensidade da manifestação cultural. As inovações tecnológicas mudaram a forma de se relacionar e o espaço de antigamente na rua vai se perdendo. A gente também percebe que cada vez menos as escolas estão preocupadas em salvaguardar o nosso patrimônio cultural. Apenas repassam essa prática como "folclore", no sentido mais pejorativo do termo. [...]. O próprio poder público deixa de investir nos polos descentralizados, ou, quando faz, não coloca essas manifestações culturais na grade de programação. [...]. Se você procurar nas periferias, acha em vários bairros menos favorecidos, mas a tradição perdeu muito espaço. (RIBEIRO apud ESTEVES, 2018).
\end{abstract}

A presença de criaturas mascaradas no carnaval de Pernambuco é comum: Caretas, em Triunfo; Caiporas, em Pesqueira; Papangus, em Bezerros; Bonecos Gigantes, em Olinda; Tabaqueiros, em Afogados da Ingazeira; La Ursas, em muitas cidades. Durante o carnaval, percebe-se, em Recife e em sua região metropolitana, uma presença marcante da La Ursa: pessoas com cabeças de La Ursas, cartazes, pinturas. A dimensão da importância da La Ursa, como imagem identitária desses lugares, é tão grande que as pessoas fazem almofadas com estampas de La Ursas, perfis em redes sociais para o personagem, charges, vasos para colocar plantas, estampas para camisetas, chaveiros e tantas outras artes e objetos. No Paço do Frevo ${ }^{9}$ há uma cabeça de La Ursa exposta (Fig. 4). As pessoas também costumam utilizar, durante o carnaval principalmente, cabeças de La Ursas como uma forma de se fantasiar (Fig. 5).

9 Espaço localizado em Recife, dedicado à difusão de pesquisas, oficinas e apresentações relacionadas principalmente ao frevo. Mas não somente a este. É um "museu do frevo". O frevo, por sua vez, é um gênero musical de Pernambuco. Muito relacionado ao carnaval, sobretudo de Recife e Olinda. Desde 2012 o frevo é Patrimônio Imaterial da Humanidade, pela UNESCO - Organização das Nações Unidas para a Educação, a Ciência e a Cultura. A palavra "paço" vem do diminutivo de "palácio". 


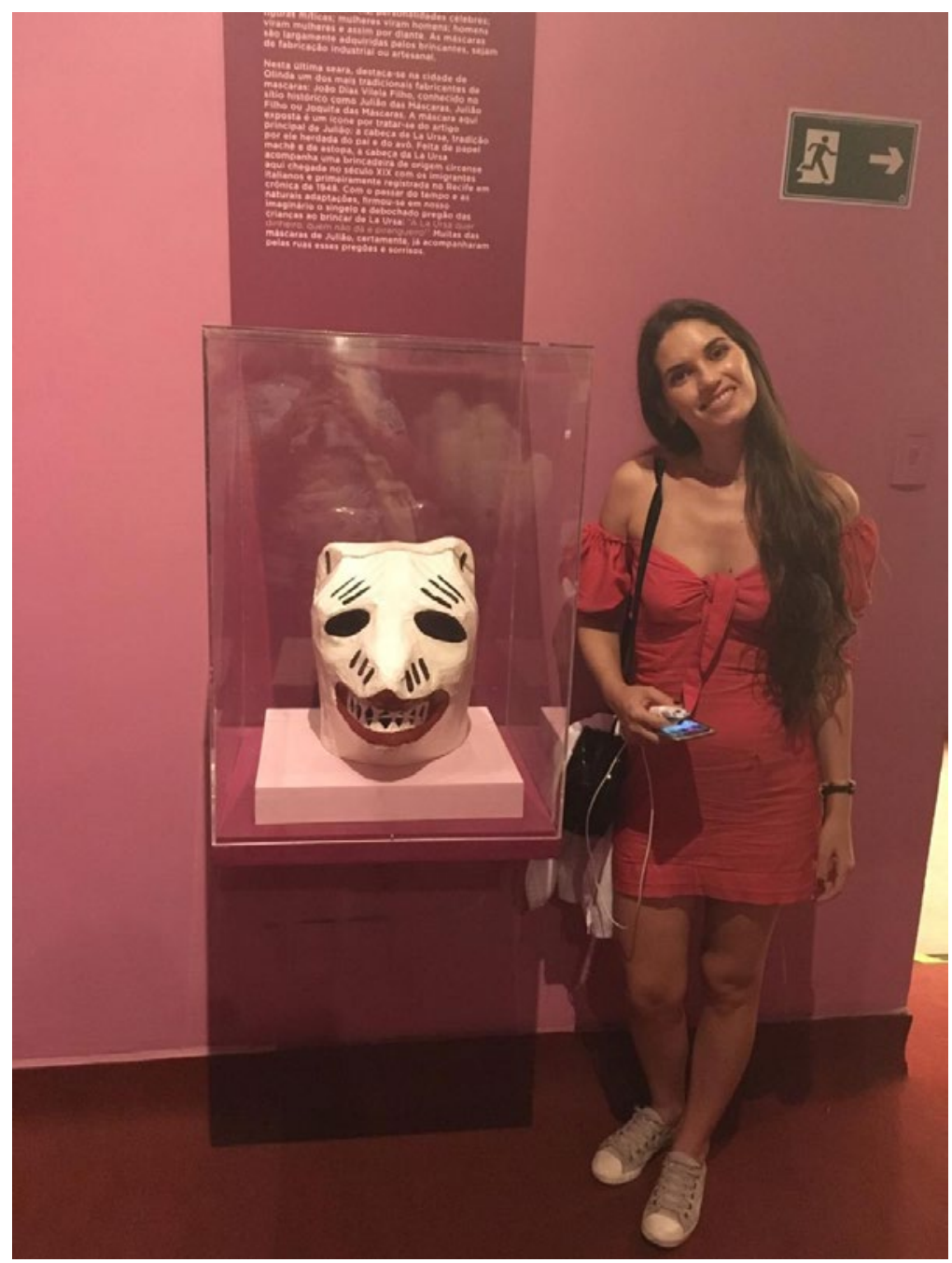

Fig. 4: Cabeça de La Ursa exposta no Paço do Frevo, em 9 de maio de 2019. Marília Santos (eu) na fotografia. Fonte: Acervo pessoal.

Há em Recife concursos de agremiações carnavalescas dos quais as La Ursas participam, apresentando elementos como estandartes e faixas, abre-alas, porta-cartazes, cordões (LIMA, 2019). Se observarmos os dados históricos, notaremos que esse é um costume que nasceu com a própria brincadeira carnavalesca da La Ursa na capital pernambucana. Real coloca, por exemplo, que os conjuntos mais elaborados de Ursos do século XX tinham porta-bandeira, que conduzia uma bandeira ou um cartaz com o nome do grupo. Ou seja, um estandarte. Duas damas, um porta-buquê, um arrecadador, duas balizas, um malabarista, que tinha a função de fazer o Urso dançar, nos remetendo à arte circense, a diretoria, "vários Ursos com cordão ${ }^{10}$ de homens e mulheres". Havia Ursos em Recife, como o Urso do Oeste, que saía com um cordão de moças que se vestiam de índias (REAL, 1967, p.122-123). 


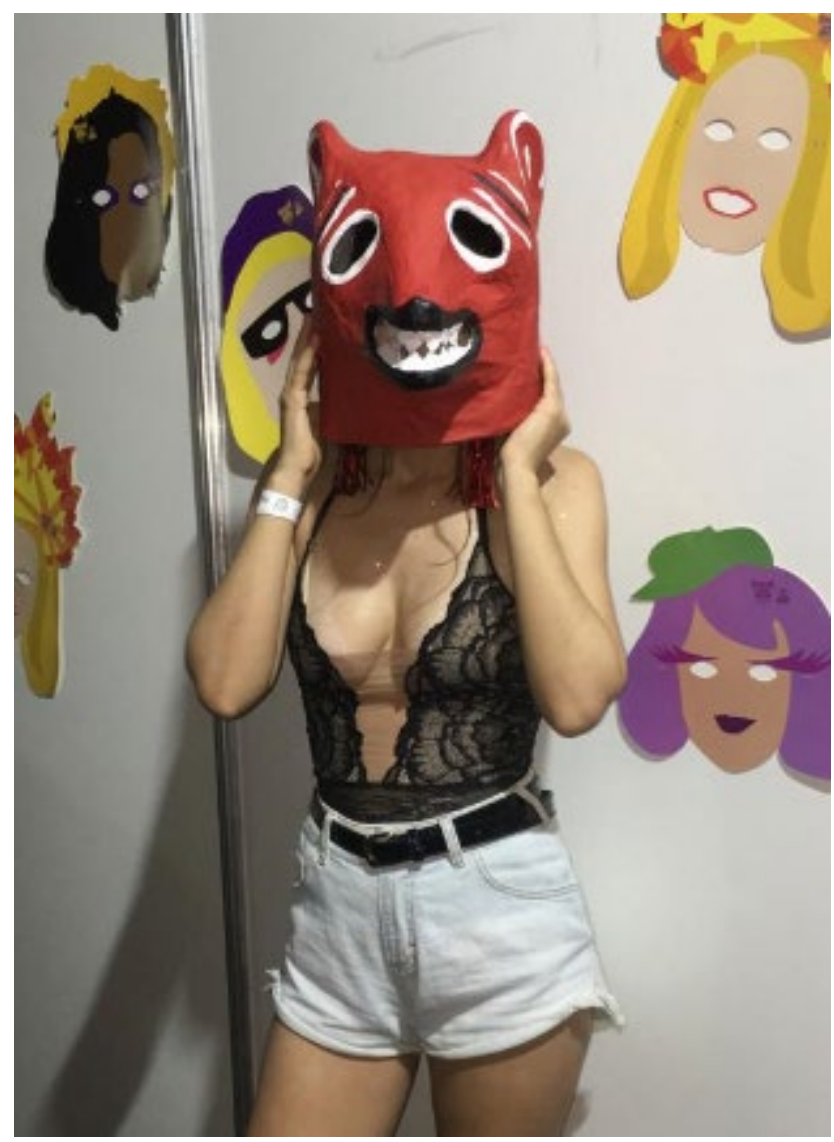

Fig. 5: Marília Santos (eu) no camarote do palco da Praça do Arsenal, em Recife, durante o carnaval de 2019. Fotografia: Acervo pessoal.

Embora ofuscada por outras expressões e brincadeiras carnavalescas do Recife e de Olinda, a La Ursa ainda se faz bastante presente na região metropolitana do Recife (GRUPOS..., 2019; BACHMANN, 2019; PESSOA, 2018). Esteves (2018) explica que alguns Ursos $^{11}$ foram fundados a partir da metade do século XX: Urso Polar de Areias (1950), Urso Preto da Pitangueira (1957), Urso Texado (1958), Urso Branco Mustardinha (1962), Urso Polar da Boa Vista (1964), Urso Minerva (1969), Urso Branco do Zé (1992). Nepomuceno (2005, p.122) explica que o encontro das La Ursas costumava acontecer no Pátio de São Pedro, no bairro de São José, em Recife.

A presença da La Ursa nos carnavais de Recife e Olinda também tem se misturado a outros tipos de grupos. A exemplo, o Bloco Lírico O Bonde, no qual a La Ursa leva uma sacolinha e uma maquineta (Fig. 6) (O BONDE..., 2020), sendo ela mesma a responsável por receber o seu dinheiro.

Os blocos líricos são grupos carnavalescos que têm como uma de suas principais características a presença de uma orquestra de pau e corda. Ou seja, um grupo musical que é formado por instrumentos de sopro, principalmente os da família das madeiras, normalmente clarinetes, flautas e saxofones, e instrumentos de cordas, frequentemente

11 É comum as pessoas se referirem à La Ursa, ou ao grupo, bloco dela, como Urso. 
as dedilhadas, como violões, cavaquinhos, bandolins, entre outros. É interessante notar que, quando Ovídio da Cunha fala dos Ursos de carnaval, ele enfatiza que houve um momento em que a predominância nos grupos era de instrumentos de cordas (CUNHA, 1948 , n.p.).

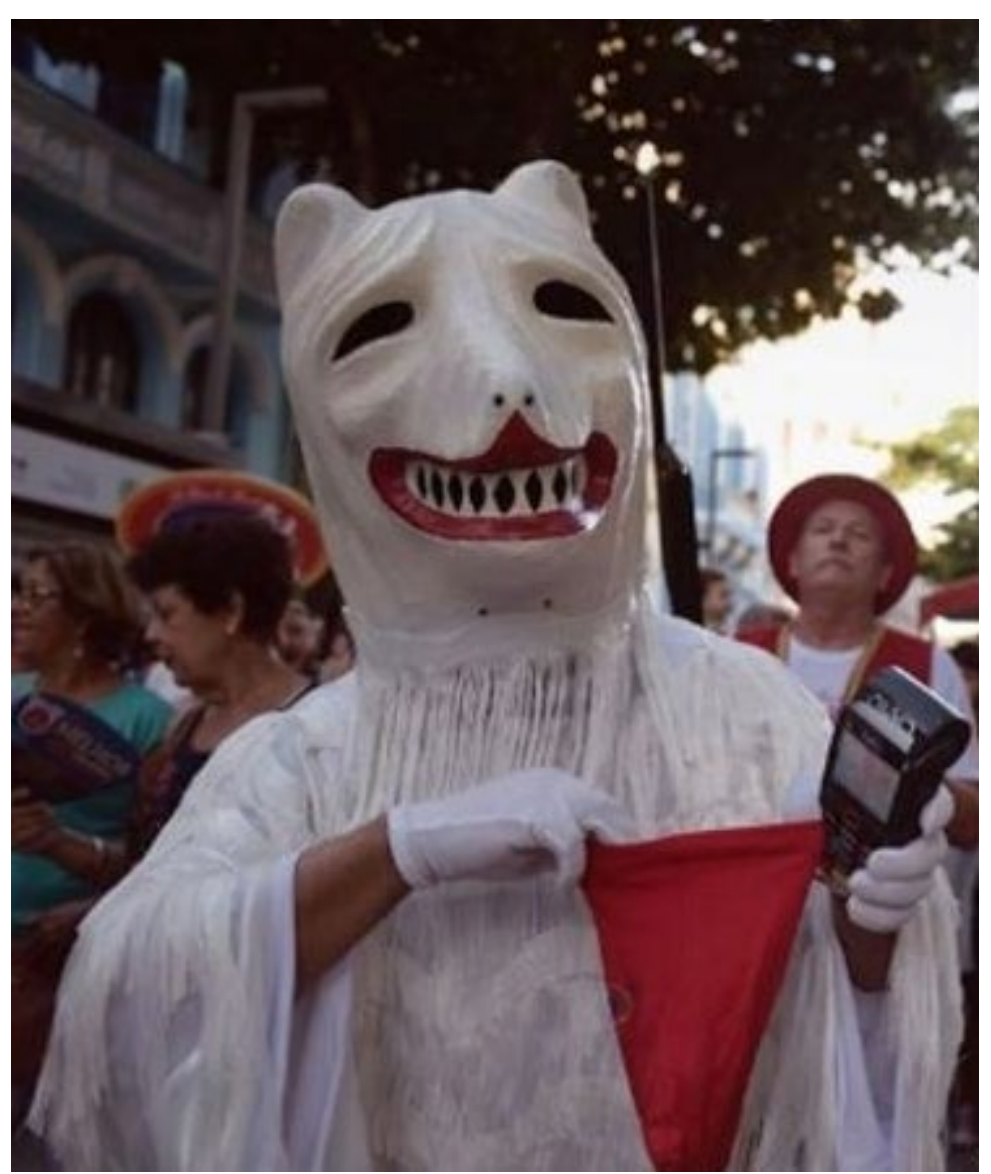

Fig. 6: A La Ursa do Bloco Lírico O Bonde com sua sacola e sua maquineta. Fotografia: Ed Machado. Fonte: Bachmann (2019).

Os meios de convencer os(as) espectadores(as) a dar dinheiro foram os mais variados na história dos Ursos: o medo, a ridicularização, a curiosidade, a brincadeira, a simpatia. Observamos que esses dois últimos foram os que transcenderam. Além disso, é possível afirmar que as pessoas são levadas a contribuir com algo por conta do que Marcel Mauss chama de dádiva social. Para ele, "a dádiva é uma lógica organizativa do social que tem caráter universalizante e que não pode ser reduzida a aspectos particulares como aqueles religiosos ou econômicos" (MARTINS, 2005, p.52).

No ano de 2020, o aplicativo educativo Museu do Homem do Nordeste, localizado em Recife e vinculado à Fundação Joaquim Nabuco de Pesquisas Sociais, desenvolveu atividades que ajudaram crianças a confeccionar fantasias de La Ursas e instrumentos musicais. Um dos objetivos era acompanhar um bloquinho de carnaval no "Domingo dos Pequenos", além de colocar fim ao medo que algumas crianças têm dos Ursos (FUNDAÇÃO JOAQUIM NABUCO, 2020).

No mesmo ano, o carnaval do município de Ipojuca, localizado na região metropolitana de Recife, teve como tema: "Do campo ao litoral: La Ursa no carnaval". Este 
município apresenta uma tradição carnavalesca antiga, tendo, atualmente, desfiles de mais de cem blocos e agremiações. O homenageado do carnaval de Ipojuca foi Amaro Tomé, presidente do bloco La Ursa Madeira do Rosarinho, que coloca troças de Urso nas ruas há mais de cinquenta anos (MARTINS, M., 2020). ${ }^{12}$

A La Ursa permanece viva no carnaval de várias cidades de Pernambuco e de outros estados. Porém, muitas vezes, para continuar existindo, é preciso passar por transformações. É isso que está acontecendo com a brincadeira em São Caitano.

\section{Transformações no carnaval das La Ursas: das portas das casas aos desfiles alegóricos}

\section{Histórias, contos, memórias}

Não se sabe ao certo quando a brincadeira da La Ursa teve início em São Caitano, cidade do agreste pernambucano. Especula-se que ela está presente no local há aproximadamente meio século. Nenhuma das informações explica como essa brincadeira teve início na cidade. Inclusive, segundo informações obtidas no site da prefeitura de São Caitano, em outros sites, blogs e por meio de pessoas, no início os Ursos saíam pelas ruas, chamando nas portas das casas, pedindo dinheiro, frutas, cereais, o que as pessoas quisessem dar. Eles cantavam e dançavam, emitindo sons com pequenos objetos. As roupas dos Ursos eram feitas com samambaias, também chamadas de ervas de passarinho, mas, com o passar dos anos, passaram a ser mais elaboradas e coloridas (CONCURSO DE..., 2018; SÃO CAETANO, 2020b; RENATA, 2018; JOHN GARÇOM, 2020), com a utilização de materiais sintéticos. É bem comum atualmente encontrar Ursos com roupas de pelúcia, por exemplo.

Xoba (2021), que atualmente tem 57 anos, nos contou que, nesse ano de 2021, mais especificamente em 5 de fevereiro, fez cinquenta anos que ele brinca de La Ursa. Ele diz o seguinte:

Eu brincava de La Ursa. Chamava os meninos. Porque naquele tempo tinha aquelas latas de bolacha "creme cáqui" [cream cracker]. Porque naquela época as bolachas "creme cáqui" era dentro de uma lata. Eu pegava a lata e começava a brincar, bater. Aí, quando foi um dia, aí eu disse: "Bora fazer uma La Ursa?". (XOBA, 2021).

A troça de Xoba é a mais antiga em atividade em São Caitano. Parte das pessoas por nós entrevistadas - o presidente da Associação das La Ursas de São Caitano, John Garçom; a diretora, produtora, tesoureira e estilista do Urso da Rua do Sapo, Marliete; o próprio Xoba e as pessoas com quem falamos informalmente sobre as La Ursas - confirma essa informação.

12 Bloco, troça e agremiações são coisas diferentes. Cada uma tem suas características próprias. Existem diferenças em relação ao status social também. 
Xoba também enfatiza que, quando ele era criança, já havia pessoas adultas que brincavam de La Ursa em São Caitano. O brincante explica que lembra de duas troças que saíam pelas ruas do município quando ele ainda estava na infância: a La Ursa do Neguinho e a La Ursa de Caetano Meia Noite. Xoba faz questão de afirmar que essas duas La Ursas tinham as roupas feitas de samambaia, que, para ele, é a verdadeira La Ursa, a tradicional (XOBA, 2021). Maria de Lourenço, que atualmente tem 69 anos, fala que havia muitos Ursos de samambaia quando ela era criança. Destaca que faz uns quarenta anos, aproximadamente, que as pessoas pararam de fazer roupas com planta para as La Ursas. E ainda completa: "Agora é cada Urso chique da gota. Com aquelas golas douradas" (MARIA DE LOURENÇO, 2021).

Quando perguntamos ao Xoba o que é samambaia, ele esclareceu:

Samambaia é uma planta. [...]. Eu tenho até a roupa de Urso aí. [...]. A planta só tem em braúna. Ela [a samambaia] gosta muito de nascer em juazeiro, que é um mato que tem muito espinho, feito braúna também. Na catingueira... Ela [a samambaia] sempre gosta de viver na catingueira. Ela também sai do mulungu. $O$ mulungu que é uma planta. E... Qual é a outra planta que ela gosta mesmo? É... Ela sempre sai na jurema. Todos os matos que têm assim as madeiras, madeira que tem leite [seiva], ela gosta de permanecer ali, na madeira mais forte, na madeira que tem leite, para ela se criar. (XOBA, 2021).

Após a entrevista, tive a oportunidade de tocar numa parte de uma roupa de Urso feita com esse material. Ao pesquisar a palavra "samambaia" na internet, o resultado é uma outra planta. A samambaia utilizada por Xoba é realmente uma planta bastante comum na Caatinga, que cresce no agreste de Pernambuco (Fig. 7).

Essa utilização de plantas na vestimenta dos Ursos de carnaval também foi relatada por Katarina Real. Ela explica que as roupas das La Ursas eram as mais variadas, desde o macacão de estopa até "tiras multicores de pano rendado", e de plantas como agave e caroá (um outro nome da bromélia gravatá). A antropóloga ainda conta que nas mãos os Ursos vestiam "enormes e grosseiras luvas de couro com garras nas pontas dos dedos, geralmente de arame" (REAL, 1967, p.123).

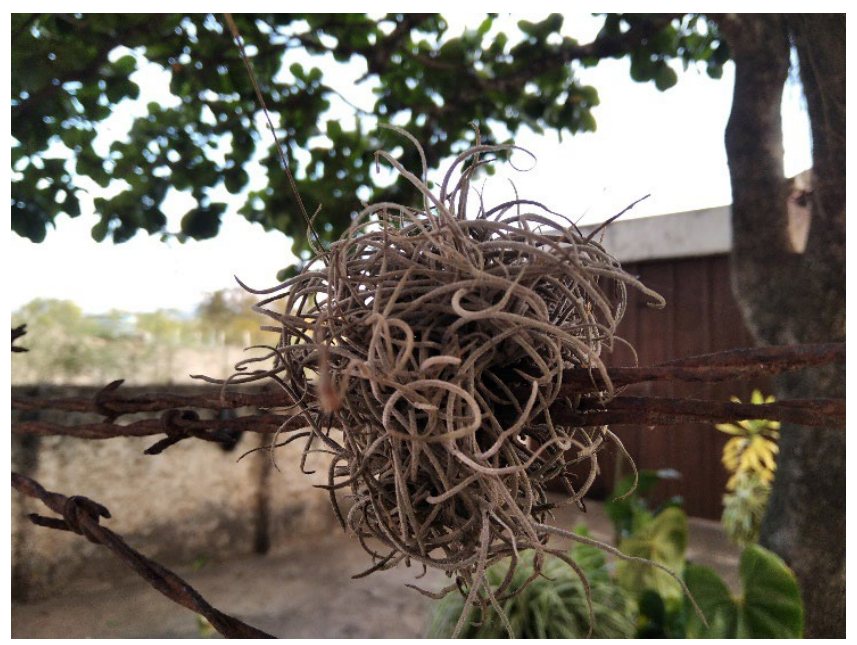

Fig. 7: Samambaia numa cerca de arame. Fotografia: Marília Santos. Fonte: Acervo pessoal. 
Não temos como afirmar se as pessoas utilizavam elementos da natureza, como plantas, na confecção das roupas por uma questão econômica, porque poderiam usar o material sem nenhum custo, ou se esse costume nasceu de outro motivo. De qualquer forma, esses relatos mostram que a La Ursa também estava integrada com o meio ambiente, ou melhor, com a flora natural do lugar geográfico onde estava situada. Todavia, nos dias atuais já não é mais dessa forma.

Em São Caitano, Xoba é a única pessoa que continua fazendo Urso de samambaia (Fig. 8). Ele explica que é ele mesmo que costura toda a roupa e que faz a cabeça, máscara do Urso. Sobre a confecção desta, ele diz: "A gente faz a forma de barro e depois a gente cobre com papelão e jornal. E grude de maisena. Depois a gente pinta. Depois, se a gente quiser tirar na fibra, a gente tira na fibra. A gente tira ela, faz o formato no papel, aí tira na fibra. Muitas pessoas estão preferindo fazer as cabeças de fibra" (XOBA, 2021).

Há cinquenta anos, de acordo com o relato de Xoba (2021), as crianças não brincavam de La Ursas em São Caitano, pois as mães não permitiam, por conta do Papa-Figo. ${ }^{13}$ Além disso, devemos mencionar que os grupos eram compostos por pessoas que estavam brincando o carnaval de diversas formas, inclusive consumindo bebidas alcoólicas. Havia também o medo de muitas crianças em relação ao Urso. Xoba ainda conta que gostava muito das La Ursas, por isso desobedecia aos pais e aos avós para acompanhar as troças, batendo em sua lata.

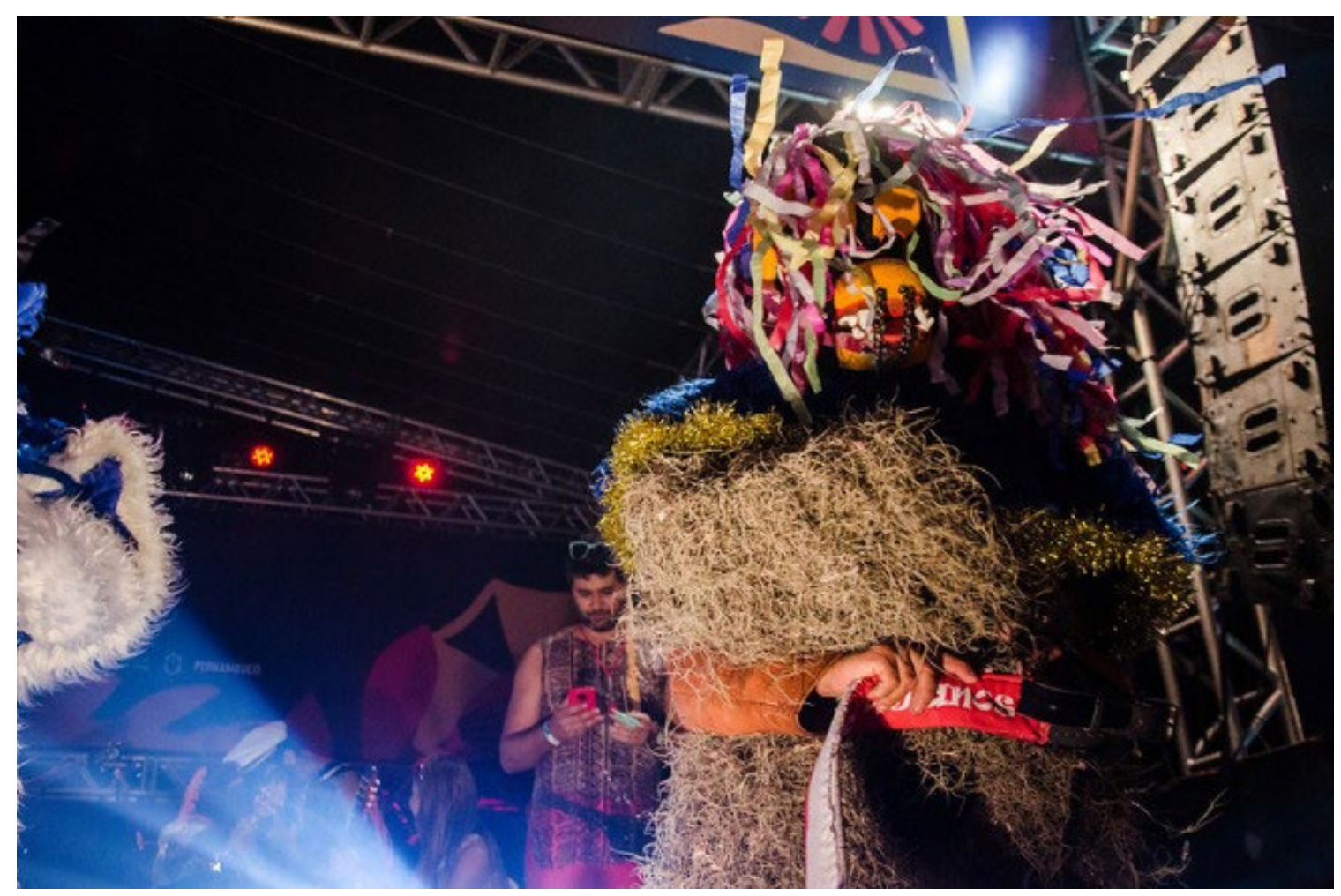

Fig. 8: Urso Maluco do Xoba, feito com samambaia, no Cais do Sertão, Recife (PE). Fonte: Reinaux (2020).

13 Também chamado de Homem ou Velho do Saco. É uma lenda que diz que essa criatura come o fígado das crianças para curar-se de uma doença. Existem algumas variações da história. Há pessoas que dizem que ele sequestra as crianças e que ele tem orelhas bem grandes. É possível deduzir que a lenda tenha surgido a partir do sequestro e assassinato de crianças, inclusive para a venda ilegal de órgãos humanos. 
Eu era mais ativo assim na época. Eu não tinha medo de nada. Eu gostava. Então não obedecia nem meu pai nem minha mãe. Porque eu gostava. Tinha vez que eu apanhava de chicote, de bainha de facão. Eu apanhava mesmo. Mas foi minha educação que os meus avós me deram. (XOBA, 2021).

Por ainda não fazer parte desses grupos, muitas vezes Xoba (2021) levava reclamações: "Eles reclamavam porque eu fazia zoada com a lata". Depois ele passou a ser chamado para tocar nas troças de La Ursas. "Eu me lembro que, quando eu era criança, eu tinha um prazer quando as pessoas me chamavam. E tinha vez que eu nem tomava café, nem almoçava... Aí meus avós diziam: 'Mas Xoba, vai pra onde?'. 'Não, que o homem disse que eu fosse logo, que é pra eu tocar'". Já falando sobre a vida adulta, ele conta que houve um momento em que não poderia participar da brincadeira porque estava doente: "Mas eu fui doente mesmo, com febre, com tudo, eu fui. Mas parece que foi uma coisa. Porque, quando terminou a batucada, eu tava bonzinho, sem sentir nada. Foi aquela emoção, né?" (XOBA, 2021).

Xoba enfatiza que, quando estava saindo da sua infância, as pessoas foram deixando de brincar La Ursa em São Caitano. Mas, como ele gostava muito da brincadeira, continuou a sua troça. "Quando Neguim morreu, eu estava com doze anos de idade. Já estava um cara que saía com La Ursa. Já tinha as batucadas de couro de bode. Que a gente matava um bode para tirar o couro para fazer os tambô". Xoba relata que já durante a sua idade adulta as La Ursas voltaram a ser mais constantes na cidade de São Caitano. Cita pessoas que tinham troças de Ursos, como Zenaide e Lula.

Durante a entrevista, Xoba lembrou de muitas pessoas que estiveram envolvidas com a brincadeira da La Ursa. Algo que nos chamou atenção é que algumas delas tiveram mortes violentas, como enforcamento, afogamento e assassinato. Contudo, nenhuma das mortes estava envolvida com o folguedo da La Ursa. Real (1967, p. 128), ao descrever o que acontecia com os Ursos de carnaval, explica que alguns eram queimados. As pessoas jogavam querosene ou cachaça no "bicho" e depois um fósforo aceso. Ela acredita que esse foi um dos motivos que fez com que, aos poucos, as pessoas fossem parando de brincar La Ursa no centro da cidade do Recife. Diferente do relato de Real, não conhecemos nenhuma história que aponte para violência contra as La Ursas em São Caitano.

Real (1967, p.128) ainda explica que na metade do século XX essas troças precisavam de uma licença da polícia para sair e brincar nas ruas de Recife. É notável como o comportamento da sociedade é distinto para os grupos carnavalescos de classes sociais diferentes. Em São Caitano, por não haver um carnaval tão diversificado entre as classes sociais, isso não é tão nítido como na região metropolitana de Recife. Porém, Xoba (2021) faz questão de afirmar que "foi o povo pobre que criou a La Ursa".

A nossa percepção é que, agora que a La Ursa está tendo mais visibilidade na cidade de São Caitano, a questão da classe econômica das troças e dos demais grupos de La Ursas é frequentemente omitida. No site da prefeitura de São Caitano, é possível ler que as La Ursas nasceram a partir de famílias tradicionais. O que são famílias tradicionais? Vemos isso como uma tentativa de esconder a realidade econômica da população 
e, principalmente, de dar credibilidade a uma classe econômica que, aparentemente, nunca contribuiu enfaticamente para a existência e difusão da brincadeira. É como se houvesse uma tentativa de "apagar" a pobreza para tornar a brincadeira "mais bonita". Além disso, a pobreza e as classes sociais economicamente baixas também revelam a falta de cuidado e compromisso que os governantes têm com a população.

Vemos pessoas (políticos, artistas, outros profissionais) que têm um status social respeitado na cidade, que são de uma classe econômica mais elevada, se interessando pela brincadeira. Perguntamos, então: por que essas pessoas não se interessaram pelas La Ursas antes? Uma vez que agora estão demonstrando interesse, por que não se preocupam em escrever, contar, pesquisar a história das La Ursas na cidade, dando os créditos devidos aos sujeitos que as compõem? Essa necessidade de relacionar a La Ursa com uma classe econômica que não é a dela é mais um meio de invisibilizar as pessoas que constituem a brincadeira, de negar as verdadeiras condições em que o folguedo é realizado. Não obstante, há pessoas que têm interesses em ajudar as pessoas que compõem as La Ursas em São Caitano.

Xoba, por exemplo, está desempregado. Não perguntamos se ele é alfabetizado. Mas, aparentemente, não é. Trabalhou como funcionário contratado na prefeitura durante mais de trinta anos. Ele nos contou que chegou a receber o auxílio do governo federal para a cultura, mas que guardou o dinheiro para usar na compra de materiais para sua troça, pois pretende voltar a fazer trabalhos com ela assim que a pandemia acabar. Ele quer ensinar as crianças a confeccionar cabeças de La Ursas e a fazer a batucada, "o toque de Xoba", como ele diz (XOBA, 2021).

John Garçom contou que todos os grupos de La Ursas da cidade foram contemplados com o auxílio do governo federal destinado para os(as) artistas e a cultura, e que combinaram em dar parte desse dinheiro, R\$ 1 mil, mais especificamente, para a Associação das La Ursas, pois como ele é o presidente desta, a mesma não pode ser inscrita para receber o auxílio. Mas houve uma pessoa, pelo menos, que não cumpriu o combinado (JOHN GARÇOM, 2021). Atitudes como esta faz com que a associação e, consequentemente, todos os grupos de La Ursas, se fortifiquem menos. Sem um pensamento coletivo, que é o que as pessoas envolvidas com a associação buscam, é quase impossível conseguir visibilidade e recursos financeiros para as La Ursas de São Caitano.

Durante minha infância, nos anos de 1990, pelo menos um mês antes do carnaval já era possível ouvir as batucadas e o som dos agogôs das várias La Ursas que brincavam pelas ruas da cidade. Havia Ursos de todos os tipos, desde aqueles com roupas extravagantes, coloridas, com glitters e máscaras grandes, bem elaboradas, até os grupos formados por pessoas que tinham seus Ursos feitos de roupas de sacos utilizados para vender farelo para gado. Crianças, principalmente meninos, sobretudo de bairros mais suburbanos, também improvisavam com o que tinham para brincar. Com caixas de papelão, criavam a cabeça da La Ursa. Muitas vezes faziam apenas os furos da boca e dos olhos, às vezes colavam papéis cortados, fitas, cordões, para representar uma espécie de "cabelo", algo bem comum nas máscaras de La Ursas em São Caitano. A banda era formada também por caixas de papelão, latas de tintas e de carregar água. Qualquer pedaço de madeira ou algo que pudesse ser utilizado como uma baqueta era usado para 
tocar. Esses objetos transformavam-se em instrumentos de percussão. Algumas pessoas conseguiam criar instrumentos mais elaborados. Xoba conta que o seu primeiro tarol foi ele mesmo quem fez, com pneu de bicicleta. "Eu esticava aquele aço que tem na bicicleta, assim dentro do pneu, esticava para fazer o jeito do tarol na lata. Até hoje eu nunca deixei de tocar tarol" (XOBA, 2021).

Como boa parte das crianças, eu tinha muito medo das La Ursas. Ao mesmo tempo, havia um encantamento por aquele personagem bonito, colorido, majestoso, que fazia meu coração acelerar quando ouvia o som perto da rua na qual eu morava. Ainda assim, quase todas as vezes eu mesma dava o agrado ao Urso. O agradecimento dele era um pulinho. Quando a La Ursa gostava muito do que recebia, fazia uma dança frenética, acompanhada por toques fortes dos tambores e demais instrumentos. Dependendo da quantidade de dinheiro e da insistência, até mostrava o rosto. A identidade das La Ursas era um mistério. Porém, mesmo sem dar um agrado financeiramente considerável, pois minha família era de classe econômica baixa, alguns Ursos eram gentis e levantavam a máscara, a pedido da minha mãe, para eu não ter medo deles. A mulher que morava do lado da minha casa, Maria de Lourenço, costumava esperar as La Ursas com muita cachaça e comida. Eu gostava de ficar espiando da janela aquela festa que faziam ao chegarem à casa dela.

Maria de Lourenço (2021) nos contou que recebia as La Ursas que ela conhecia. Muitas das pessoas que estavam embaixo da roupa do personagem eram mulheres. Dentre elas, a entrevistada lembra do nome de três: Quitéria, Têca ou Têta, e sua comadre Givaneide. Das La Ursas que saíam das ruas próximas à casa dela, ela recorda-se do Urso de João Caetano, Urso de Dida e Urso de Lula. Ela conta:

Achava bonito. O povo fechava as portas. Eu abria para eles entrar. Carnaval agora não tem graça. Eles [os Ursos] ficam só lá pela rua. ${ }^{14}$ Aquilo era uma beleza. Era a coisa mais linda do mundo. Eu acho que o povo não dá mais nenhum trocado para os Ursos, por isso eles não sobem para cá. Agora eles só dançam na rua. A gente esperava o carnaval todo... E eles não sobem mais por aqui. ${ }^{15} \mathrm{Ah}$, eu achava muito bom quando vinham aquelas Ursas. Eu trocava dinheiro para dar às La Ursas. Eu não dava de pouco, não. Por isso os Ursos gostavam de subir para cá. Só uma casa já valia pela rua toda. Eu colocava vinho, melancia, bolo para eles. Cachaça com limão. (MARIA DE LOURENÇO, 2021).

O ato de fechar as portas para as La Ursas é um dado interessante. Algumas pessoas simplesmente não gostavam da brincadeira. Mas outras não tinham o que oferecer para o "bicho". Essas são cenas de bairros da periferia de São Caitano.

Apesar de gostar da brincadeira, Maria de Lourenço nunca saiu de La Ursa no carnaval. Ela conta: "Vontade eu tinha. Mas eu não tinha chance. Não tinha tempo. Mas eu acho que eu pagaria caro para andar num Urso daquele, pulando. Mas, com os compro-

\footnotetext{
14 Nesse contexto, "rua" é o centro da cidade. Em São Caitano as pessoas dizem que vão para a rua quando estão indo para o centro. A expressão também é utilizada pelas pessoas que vivem na zona rural quando estão indo para a zona urbana do município.

15 A cidade de São Caitano fica situada num terreno com pequenos relevos. Poucos bairros, incluindo o centro da cidade, que estão próximos ao rio, o Ipojuca, ficam num terreno mais plano. Os demais bairros ficam em terrenos mais elevados.
} 
missos que eu tinha, eu não podia participar. Filho, marido... Eu sempre estava costurando" (MARIA DE LOURENÇO, 2021).

Além do domador, que na La Ursa de São Caitano segurava o Urso por uma corda ou uma corrente, às vezes pela cintura do "bicho", outras vezes pelo focinho, havia mais personagens que acompanhavam o grupo. A Catirina era um deles. Catirina, ou Papangu, é uma pessoa mascarada. Seu objetivo é brincar o carnaval sem ser reconhecida. Catirinas também saíam de maneira independente às La Ursas. Antigamente saíam pelas ruas, chamando nas casas, pedindo coisas. Não encontramos nenhuma fonte escrita sobre esse personagem, porém é possivel deduzir que nasceram do hibridismo de alguns outros, como a Catirina do Bumba meu boi e os Papangus de Bezerros. As Catirinas normalmente usavam máscaras monstruosas e vestiam roupas que criavam um personagem humano (uma velha, um noivo, uma noiva, uma mulher, um médico), roupas velhas ou roupas que cobrissem todo o corpo para não serem reconhecidas, pois, assim como as La Ursas, a identidade das Catirinas também era secreta. Algumas carregavam um cacete, confeccionado com algum galho de árvore, cabo de vassoura ou qualquer outra coisa que pudesse ser usada como o objeto. A Catirina era um meio de estar fantasiado(a). Numa acepção geral, poderíamos até dizer que todas as pessoas fantasiadas e mascaradas do carnaval são Catirinas.

Nesse sentido, Maria de Lourenço, que durante os últimos carnavais tem costurado roupas para os grupos e troças de Ursos, explica que, além das roupas de pelúcias de Ursos, também já costurou roupas para Catirinas. E exemplifica dizendo: "Papangu de Caça-Fantasma, fantasias da Turma do Chaves. E aquelas roupas de pelúcia dos Ursos. Tudo igual. Porque agora eles estão dançando com vários Ursos na rua" (MARIA DE LOURENÇO, 2021).

Maria de Lourenço recorda-se dos personagens que acompanhavam a La Ursa: "Tinha Cavalo-Marinho, com Burro, com Boi. As Burras pulando no meio da rua". E completa me dizendo: "Tu morria de medo. Uma vez tava tu e tua mãe na rua e passou um Cavalo-Marinho. Para te acalmar, eu disse que era Marcelo. ${ }^{16}$ Aí foi que tu chorou. E não quisesse nem chegar mais perto de Marcelo" (MARIA DE LOURENÇO, 2021). Após ouvir o relato dela, recordei-me de como eu sentia medo dessa criatura, por conta do comportamento do "bicho".

O Cavalo-Marinho (Fig. 9) normalmente era um personagem bravo. Sua roupa era como se realmente fosse um cavalo, em que a pessoa ficava dentro. As crianças mais traquinas puxavam o rabo do personagem, que corria atrás delas, muitas vezes com um chicote. Assim como sobre as Catirinas, não encontramos uma definição para esse personagem. É possível deduzir que ele tem referências baseadas no Bumba meu boi. Também devemos considerar que o personagem Cavalo-Marinho pode ter alguma relação com o folguedo Cavalo-Marinho, que, assim como o Bumba meu boi, também tem o Boi como um dos seus personagens. O chicote, que alguns dos Cavalos-Marinhos carregavam, pode ter relação com os Caretas, que são personagens que, durante o carnaval, saem pela cidade de Triunfo, realizando performances, brincando, com seus

16 Um dos filhos dela. 
chicotes longos. Porém, Xoba (2021) explica que esse personagem representa o vaqueiro do agreste e do sertão de Pernambuco. Não fica claro se esse já era o significado do Cavalo-Marinho ou se foi uma ressignificação feita pelo brincante.

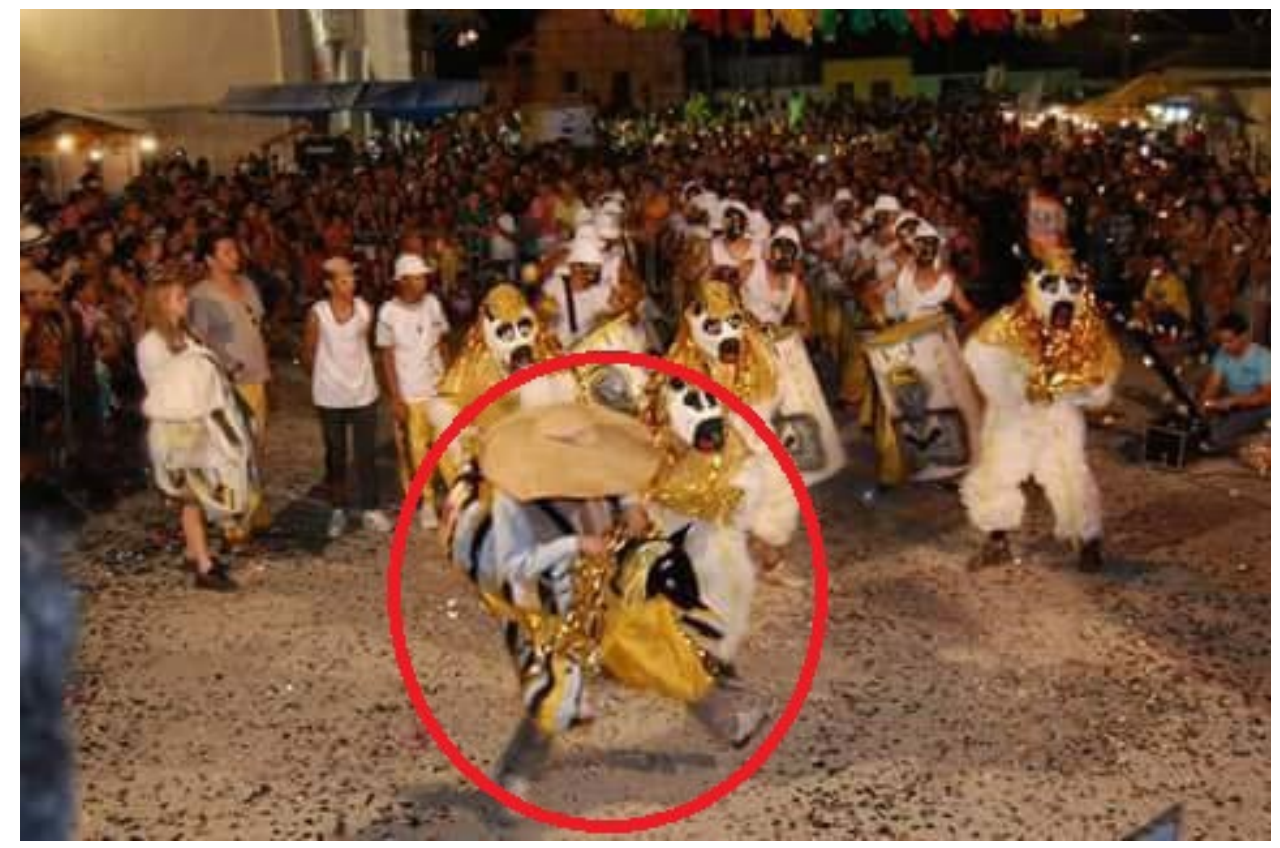

Fig. 9: Cavalo-Marinho numa apresentação recente das La Ursas de São Caitano. Fonte: Fotografia enviada por John Garçom.

É importante enfatizarmos que, por ser comum as pessoas usarem fantasias durante o carnaval, personagens diversos apareciam acompanhando as La Ursas. Um deles era o Satanás, ou Cão, que às vezes também levava consigo um chicote. As pessoas fantasiadas, desde a La Ursa até as diversas figuras que surgiam durante o carnaval acompanhando a brincadeira, interpretavam seus respectivos personagens, muitas vezes com características criadas por elas mesmas. Mas o mais comum era ser feroz, correr atrás das pessoas ameaçando bater nelas com um chicote ou um cacete.

Xoba diz que não gosta de colocar o Satanás na sua troça e ainda enfatiza que também não gosta quando outros grupos usam imagens de entidades religiosas, como Nossa Senhora, por exemplo. Para ele, religião e carnaval são coisas separadas. Ele gosta de usar animais selvagens, como o gorila ou o macaco. O brincante também conta que há personagens que são da tradição das troças de La Ursas, como as meninas vestidas de índias; a Mulher da Trouxa, que é um boneco gigante; o Morto-Vivo, que, segundo Xoba, representa as pessoas que foram assassinadas e tiveram seus corpos abandonados no meio da caatinga; o Bumba meu boi. Este, na troça de Xoba, tem uma cabeça empalhada de um boi de verdade. O brincante ainda se recorda de um outro personagem: a Mariana, uma boneca que saía na troça de Zenaide (XOBA, 2021). Ele recorda-se cantando os seguintes versos:

Você conhece a Mariana

É uma linda criatura

Nos sete dias da semana 
Ela só quer gordura.

(XOBA, 2021).

Aos poucos as pessoas foram deixando de brincar La Ursa da forma tradicional, em que os grupos saíam pelas ruas, passando de porta em porta para pedir coisas. Os grupos ainda saem nas ruas, mas não como há vinte anos, por exemplo. Xoba (Fig. 10) é uma das pessoas que têm brincado com a La Ursa em São Caitano, mesmo num período em que não havia o Concurso das La Ursas atual (sobre o qual falaremos ainda nesse artigo). Xoba tem tanta importância para as La Ursas de São Caitano que o seu "Urso Maluco" (Fig. 10) é a La Ursa que aparece na divulgação do carnaval das La Ursas da cidade (Fig. 11). Além disso, Xoba, com sua La Ursa, se manteve realizando a brincadeira da forma mais tradicional, assim como tem se adaptado às mudanças pelas quais o folguedo está passando. Ele gosta de vestir-se de vaqueiro.

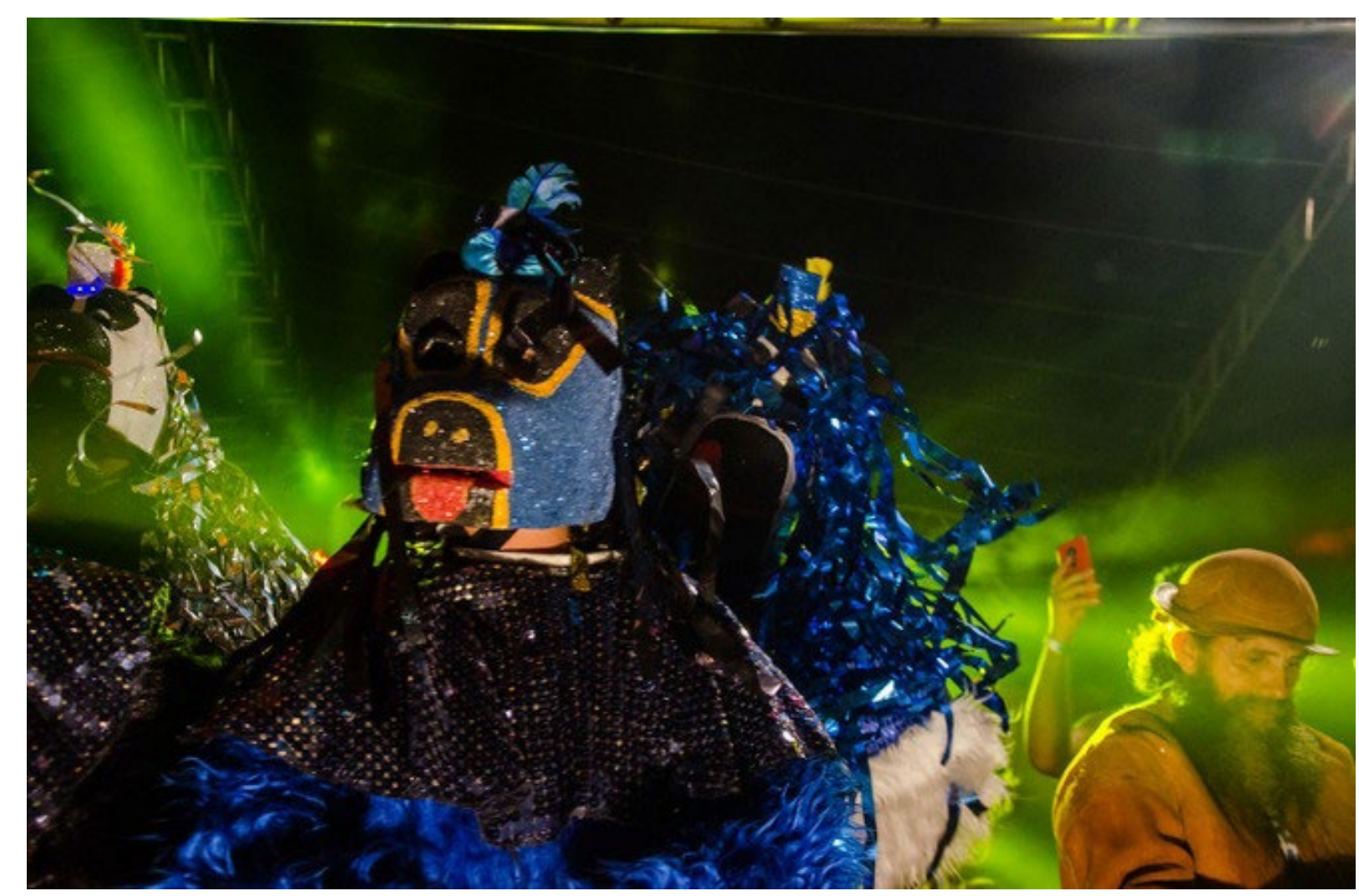

Fig. 10: Da esquerda para a direita: La Ursas de São Caitano e Xoba, no Cais do Sertão, Recife (PE). Fonte: Reinaux (2020).

Segundo ele mesmo, a tradição da La Ursa se mantém quando as pessoas saem com as troças passando pelas ruas da cidade, pedindo algo nas casas, na feira. Xoba ainda costuma fazer isso. Sua troça é composta por quem quiser brincar: homem, mulher, adulto, criança. $O$ que arrecada na brincadeira, ele usa para fazer confraternizações com os componentes da troça. Conta que, para as crianças, costuma comprar biscoito e refrigerante e, para os adultos, bebida alcoólica, porque eles gostam. Além disso, para manter a tradição, Xoba acredita que os Ursos devem ter o macacão feito de samambaia (XOBA, 2021). 
De acordo com Maria de Lourenço, o carnaval em São Caitano já não é mais tão animado como há trinta, quarenta anos. Ela enfatiza: "Quando eu era menina, moça, e também já casada, tinha o Bloco do Seu Humberto. ${ }^{17}$ Tinha carnaval na cidade. Mas depois, com esses outros prefeitos, o carnaval foi esmorecendo" (MARIA DE LOURENÇO, 2021). Xoba também chama atenção para a brincadeira de Zé Pereira, que acontecia até uma década atrás, pelo menos, com ele mesmo empurrando uma pessoa fantasiada de Zé Pereira, numa boia, dentro do rio Ipojuca, na noite do sábado de carnaval. Ele diz que as pessoas não têm se preocupado em manter a tradição (XOBA, 2021).

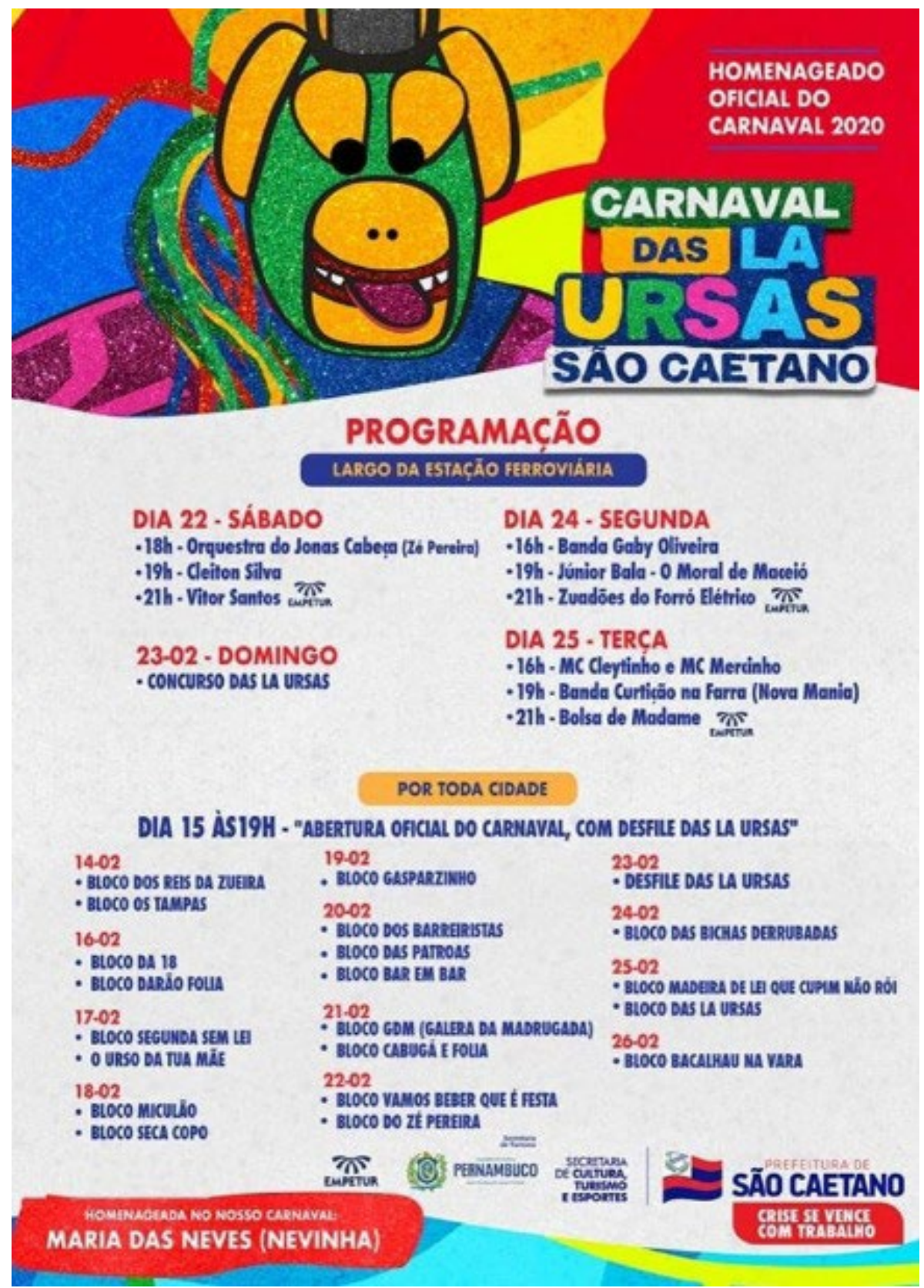

Fig. 11: Cartaz da programação carnavalesca 2020 de São Caitano. Fonte: Silva (2020).

17 Um ex-prefeito já falecido de São Caitano. 
Por outro lado, como o cartaz (Fig. 11) mostra, a cidade de São Caitano teve, pelo menos no último carnaval, que foi o de 2020, vários blocos, inclusive um chamado "Bloco das La Ursas" e um outro "O Urso da tua Mãe." Aqui, aparentemente o imaginário do Urso como amante volta a ser referenciado. Ao observar a programação, temos conhecimento de que quase todas as atrações musicais são de pessoas que vivem em São Caitano e que não sobrevivem, em sua maioria, de música. Não vemos nenhuma movimentação dos poderes públicos em relação aos artistas da cidade.

Notamos, a partir das atrações (Fig. 11) e do que conhecemos dessa mais recente maneira de brincar carnaval em São Caitano, que a estética da cachaça-cabaré-gaia está cada vez mais inserida nessa folia de Momo. As atrações e músicas tocadas, além das tradicionais carnavalescas, também transitam pelo forró estilizado, pelo sertanejo universitário e até pelo brega-funk, além das músicas que estão "na moda". Tudo isso é motivo para beber, dançar, se divertir e ainda juntar com o imaginário do Urso. Não conseguimos identificar diretamente um caráter religioso nas La Ursas em São Caitano. Talvez isso apareça individualmente, quando as pessoas brincam se vestindo de Satanás, por exemplo. Uma religiosidade cheia de profanação e irreverência.

Em 2013 foi criado o concurso das La Ursas em São Caitano. O presidente da Associação das La Ursas de São Caitano, John Garçom, explica que, antes de haver o concurso, as La Ursas já faziam, alguns anos antes de 2013, o seu desfile no domingo que antecede a terça-feira de carnaval. Esta era uma maneira de os grupos de La Ursas se apresentarem para a população (JOHN GARÇOM, 2019). Xoba (2021) completa explicando que há décadas as La Ursas se reúnem na cidade para se apresentar para a população.

Marliete conta que

\begin{abstract}
A La Ursa passou a se tornar mais conhecida a partir de 2007, quando o secretário de Cultura da época, o Sr. Caetano Vieira, criou um concurso para avaliar qual das La Ursas dançava melhor. A apresentação acontecia no centro da cidade e a La Ursa dançava em cima de um caminhão. E os tocadores e torcedores ficavam embaixo. E foi neste ano que o Urso da Rua do Sapo foi campeão pela primeira vez. Com o passar dos tempos, este concurso foi evoluindo e chegou a ter doze grupos de La Ursa participando. Nos últimos anos, com o apoio da Sra. Veridiana Fortunato como secretária de Cultura, o concurso foi evoluindo. E a cada ano está conquistando a comunidade em geral. (MARLIETE, 2021).
\end{abstract}

Atualmente Veridiana Fortunato não é a secretária de Cultura da cidade.

Percebemos que aos poucos vão sendo acrescentados às La Ursas elementos que inovam a tradição. Ao realizarmos algumas conversas informais, há pessoas que dizem que o carnaval das La Ursas em São Caitano, assim como o concurso das mesmas, tem como objetivo resgatar a brincadeira - o que é um equívoco, visto que a manifestação não estava "perdida", nunca deixou de existir, para ser resgatada. O que presenciamos são transformações na brincadeira.

John Garçom explica que, nos dias que antecedem o desfile, há cortejos na cidade com os grupos de La Ursas. No ano de 2020, os prêmios para os grupos vencedores do 
concurso foram de $\mathrm{R} \$ 5$ mil, R\$ 4 mil e $\mathrm{R} \$ 3$ mil para os três primeiros lugares, e troféus. Além disso, todos os grupos que participam do concurso ganham um prêmio de participação. John Garçom não especificou que tipo de prêmio é esse (JOHN GARÇOM, 2020).

Notamos que, pelo fato de a La Ursa ser a única expressão carnavalesca que existe na cidade de São Caitano, as gestões dos últimos anos têm buscado destacá-la. De acordo com John Garçom (2020), em 2014 foi criada a Associação das La Ursas de São Caitano, mas somente em 2019 ela foi oficializada, com a ajuda de Ênio Quirino. ${ }^{18}$

Logo após isso, os responsáveis pelos grupos das La Ursas em São Caitano, junto com Ênio Quirino, Rodrigo Novais, com apoio da Fundação do Patrimônio Histórico e Artístico de Pernambuco (Fundarpe) e da prefeitura da cidade de São Caitano (gestão de 2017-2020), conseguiram oficializar São Caitano como a Cidade das La Ursas (JOHN GARÇOM, 2020; ÊNIO QUIRINO, 2020). A ideia, como veremos, é manter viva a tradição da La Ursa e buscar desenvolver uma cadeia turística e produtiva em São Caitano, baseada na cultura.

Ao entrevistarmos Rodrigo Novaes, ele colocou o seguinte:

As La Ursas [estão presentes] em vários municípios, principalmente no litoral. A gente tem a presença das La Ursas no período de carnaval. E é algo que está inserido no cenário cultural. Mas em São Caitano a gente veio descobrir, eu, pessoalmente, vim descobrir recentemente o trabalho que é feito, as apresentações, a competição, a mobilização que acontece na cidade, com tantas pessoas indo pras ruas, pras calçadas. A organização das associações, ${ }^{19}$ que passam o ano todo se programando. As fantasias, os temas que são discutidos, é tudo muito interessante. Se assemelha a uma escola de samba, com perfis e características próprias. E realmente é algo encantador. $\mathrm{E}$ a gente fica muito animado. Eles estiveram aqui no Recife, no Marco Zero. Fizeram uma belíssima apresentação. Chamaram a atenção de todos. É algo que precisa ser mais conhecido, em Pernambuco e fora do nosso estado (RODRIGO NOVAES, 2020).

Em 2020 as La Ursas de São Caitano foram homenageadas pelo carnaval de Pernambuco. Acreditamos que isso tenha acontecido por influência do então secretário de Turismo do estado, como uma maneira de apresentar a La Ursa de São Caitano para Pernambuco, visto que muitas pessoas não sabem da existência da brincadeira na cidade e, consequentemente, para expandir a imagem de São Caitano, relacionando-a com a brincadeira. A homenagem feita pelo carnaval do estado saiu em reportagens, como a seguinte:

O "Bora Pernambucar no Carnaval" promoveu, neste domingo [9/2/2020], Dia do Frevo, um verdadeiro encontro da cultura popular para celebrar o aniversário deste que é um Patrimônio Imaterial da Humanidade com 113 anos de história. O último dia da programação feita para animar a temporada pré-carnavalesca,

18 Enfermeiro e primo do atual secretário de Turismo do estado de Pernambuco, Rodrigo Novais. Em 2021 Ênio Quirino assumiu seu primeiro mandato como vereador da cidade de São Caitano, embora ele seja natural da cidade de Floresta (PE). Mas reside em São Caitano há muitos anos. Observamos, através das redes sociais, que algumas pessoas envolvidas com grupos de La Ursas o apoiaram durante a sua campanha eleitoral.

19 Acreditamos que ele queria se referir aos grupos, pois existe somente uma associação. 
promovida pelas secretarias de Cultura e Turismo do Estado, Fundarpe e Empetur, contou ainda com uma homenagem às La Ursas de São Caetano [sic] (Fig. 12), uma das principais manifestações culturais de Pernambuco, além de um grande encontro entre o Homem da Meia Noite, Patrimônio Vivo do estado, e Zé Pereira e Vitalina, bonecos gigantes que fazem a folia de Momo acontecer em Belém de São Francisco - e que chegaram de barco, no Cais do Sertão, ${ }^{20}$ para comemorar o aniversário do frevo. A noite encerrou com shows da Orquestra Malassombro e da figura carimbada no Carnaval de Pernambuco, o cantor Alceu Valença. (PERNAMBUCO, 2020, grifo nosso).

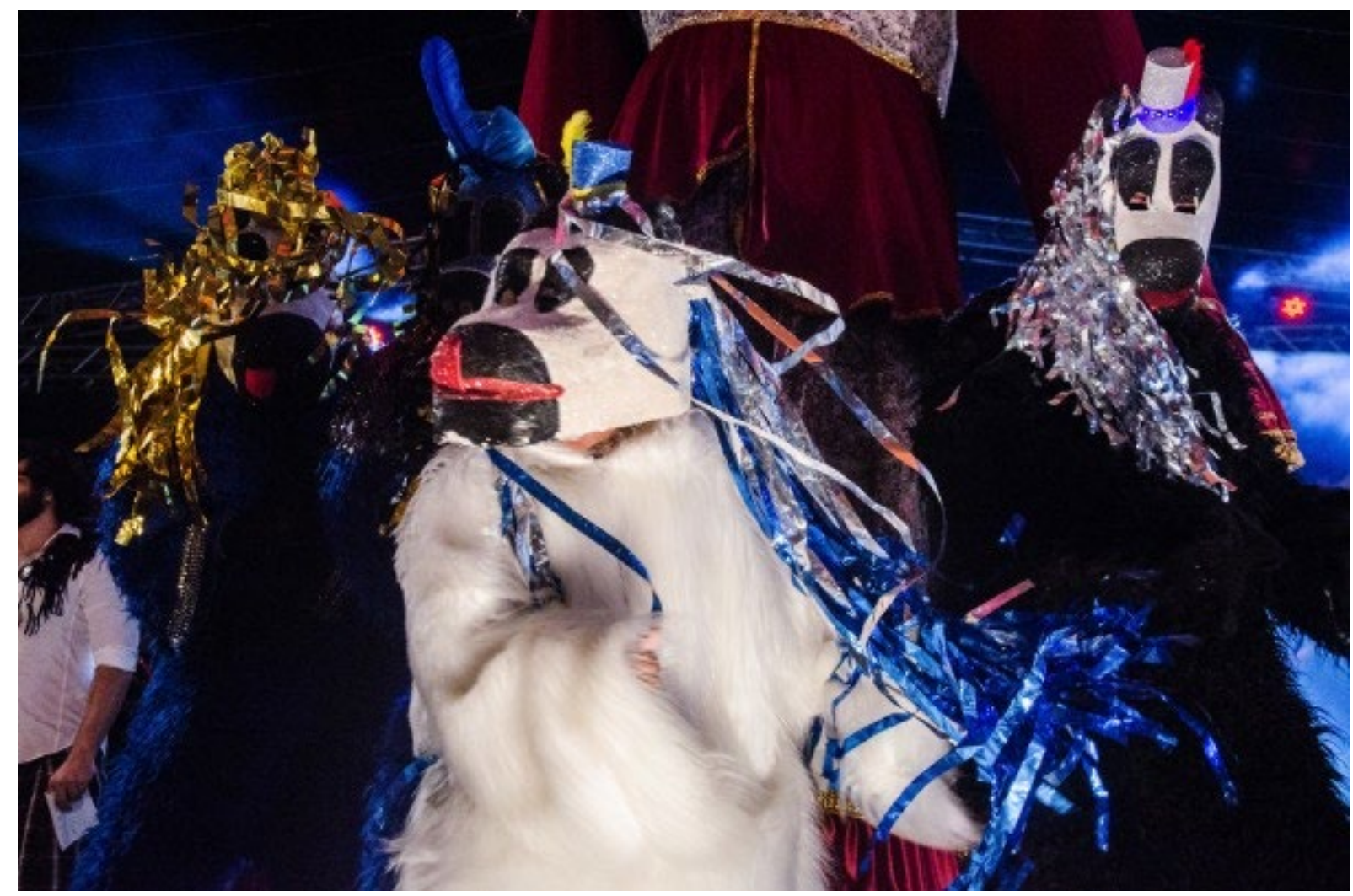

Fig. 12: La Ursas de São Caitano no Cais do Sertão, Recife. Fotografia: Jan Ribeiro. Fonte: (PERNAMBUCO, 2020).

\title{
Rodrigo Novaes explicou um dos objetivos do Bora Pernambucar e alguns dos
} motivos que levaram São Caitano a ser oficializada como a cidade das La Ursas:

\begin{abstract}
Uma das perspectivas que temos com o projeto Bora Pernambucar é justamente o intercâmbio cultural entre as cidades e regiões pra que a gente faça com que o turismo interno funcione, promovendo desenvolvimento, diminuindo desigualdades sociais e regionais. A identificação de um marco, de um símbolo cultural nas cidades é algo fundamental nesse processo. Em São Caitano, as La Ursas acontecem há muito tempo, há décadas, mas as pessoas ainda não conheciam as La Ursas como algo marcante na cultura de São Caitano. Então a gente começou esse processo ano passado, fizemos um trabalho de divulgação, trazendo
\end{abstract}

20 É um museu que se dedica principalmente, mas não somente, à memória cultural do sertão de Pernambuco e a Luiz Gonzaga. No prédio há espaços para realizar vários tipos de eventos, além do espaço dedicado ao museu. Ele fica localizado próximo ao Marco Zero do Recife, chamado costumeiramente de Recife Antigo. 
as La Ursas pra Recife. Foi homenageada do Carnaval [desse ano] ${ }^{21}$ pelo governo do estado. A gente vai continuar esse trabalho de fortalecimento pra que a gente consiga marcar São Caitano como a terra das La Ursas. E, através disso, desenvolver uma cadeia voltada pro fortalecimento da cultura e do turismo no município. (RODRIGO NOVAES, 2020).

Embora haja essa intenção, não vimos durante o ano de 2020 ações que fortificassem a imagem de São Caitano como a Terra das La Ursas, que promovessem o turismo baseado nisso nem que criassem meios de gerar renda para a população e para o município. Entretanto, 2020 foi um ano difícil, em quarentena desde o final do carnaval, por conta da pandemia causada pela Covid-19. Em 2021, de acordo com Xoba (2021) e Marliete (2021), também não houve nenhuma atividade remota realizada em São Caitano. Nenhuma ação da nova gestão municipal nem do governo do estado foi promovida junto com as La Ursas. Marliete conta que o Urso da Rua do Sapo participou do VI Encontro de Bois, Ursos e Similares de Arcoverde, de maneira remota, em dezembro de 2020.

\section{A música (o som) das La Ursas em São Caitano}

Um dos elementos essenciais na La ursa de São Caitano é a música, o som. “Na concepção ocidental, o som sempre teve algo de misterioso. Onipresente e, ao mesmo tempo, evanescente, o som não se rende facilmente a um raciocínio acostumado com coisas, locais e configurações estáveis" (PINTO, 2001, n.p.). Nas La Ursas de São Caitano, esse som era realizado basicamente por instrumentos de percussão, sobretudo membranofones. Se esse som era música? Talvez. Teríamos que entrar numa discussão mais profunda sobre o que é música ou quando é música, quando o som não é música e como esse som, ou música, era tratado pelas pessoas que o produziam e consumiam. Embora haja vários estudos sobre isto, não é nossa intenção abordar essa discussão. Logo, para esse artigo, vamos tomar uma classificação provisória de que todo som realizado pelas La Ursas em São Caitano é música.

Devemos mencionar que, de acordo com Gleybinho (2021), um dos organizadores da parte musical do Urso da Rua do Sapo, esse som que as La Ursas realizam é música. Ele coloca o seguinte:

Eu não sou o responsável pela música. A gente escolhe música em conjunto e eu que ordeno qual música vai ser tocada. Mas [as músicas] são escolhidas pelo grupo e por algum amigo que tem alguma música e passa para a gente. A gente escolhe e eu fico responsável para ensaiar o pessoal da bateria. (GLEYBINHO, 2021).

Por outro lado, Xoba não chama de música, mas de batucada. Ele diz o seguinte: "A minha batucada é diferente de tudinho. É a original de antigamente. Eu nunca deixei a origem" (XOBA, 2021).

21 Na entrevista, ele disse "ano passado". Acreditamos que foi um deslize por ter comentado que esse trabalho de fortalecimento vem sendo feito desde 2019. As La Ursas de São Caitano foram homenageadas pelo carnaval de Pernambuco em 2020, mesmo ano em que Rodrigo Novaes nos concedeu a entrevista. 
Embora a maior parte dos grupos de La Ursas em São Caitano continue utilizando apenas instrumentos de percussão, alguns já começaram a empregar aerofones. Percebe-se a presença de trombones e trompetes, por exemplo, talvez como resquício das práticas das bandas marciais e fanfarras. Os desfiles lembram uma mistura das escolas de samba, do Rio de Janeiro e de São Paulo, com os desfiles cívicos que aconteciam no final dos anos 1990 em São Caitano, durante o aniversário de emancipação da cidade (11 de setembro). Há alguns anos, nunca havíamos ouvido falar em bateria de La Ursa. Recordo-me de ouvir a palavra "banda" para se referir ao grupo de músicos das La Ursas. Gleybinho (2021) explica que os grupos de Ursos decidiram chamar o grupo musical de bateria. Xoba (2021), por outro lado, não gosta do nome. Para ele, é troça. Todo o conjunto é a troça. Embora em alguns momentos as troças da La Ursas tenham aparecido em São Caitano com uma predominância de homens, notamos, inclusive por meio dos relatos históricos e do material bibliográfico, que mulheres sempre estiveram presentes na brincadeira. De acordo com Xoba, muitas mulheres e meninas também participavam dançando, e depois como as rainhas das troças. Agora, nos mais recentes grupos de La Ursas, notamos que essas mulheres são chamadas de rainhas de bateria. Assim como as rainhas das escolas de samba, elas desfilam com roupas curtas, calçados com saltos altos e grandes adereços na cabeça.

Embora haja versões, como mostramos na primeira parte desse artigo, que dizem que inicialmente o som das La Ursas era feito somente para incomodar, para que as pessoas contribuíssem com algo, não temos relatos de que isso acontecia em São Caitano. O que temos conhecimento é que os grupos das La Ursas tocavam ritmos com uma intenção musical. De acordo com Pinto, "música raras vezes é apenas uma organização sonora no decorrer de limitado espaço de tempo". Ela "está quase sempre em estreita conexão com outras formas de cultura expressiva". A música, desse ponto de vista, é entendida como uma espécie de linguagem, com seus códigos particulares, sendo difícil traduzi-la fora do seu contexto (PINTO, 2001, n.p.). Desta forma, se houve transformações na brincadeira da La Ursa, a maneira de fazer a sua música também mudou.

Não conseguimos nenhum vídeo ou áudio para compararmos a música realizada pelas La Ursas nos anos 1980 e 1990 com a produzida atualmente. Porém, tenho na memória um toque de um idiofone, provavelmente agogô, que repetia inúmeras vezes algo mais ou menos com o seguinte ritmo (Fig. 13):

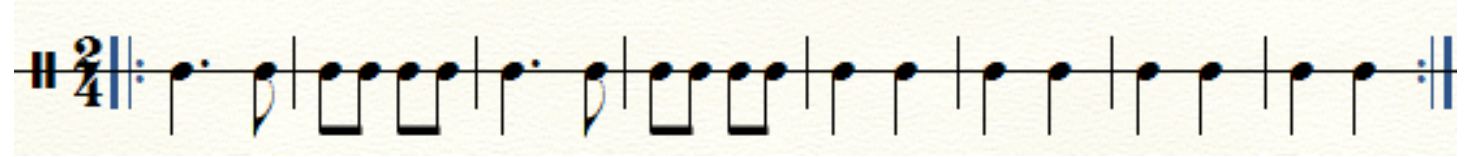

Fig. 13: Provável ritmo realizado pelas La Ursas em São Caitano nos anos 1990. Fonte: Elaboração própria.

Ao mesmo tempo, ouvia-se de alguns dos membranofones a marcação a cada pulsação (semínima, num compasso que tem a mínima como unidade de compasso), sendo um forte e o outro fraco, no ritmo do passo dos integrantes, uma espécie de marcha. No caso da La Ursa, não foi criado um gênero musical específico. Abrange-se, 
atualmente, uma grande variedade de gêneros e ritmos durante os desfiles. Alguns grupos tocam frevo, que é algo bem característico do carnaval pernambucano, outros tocam ritmos que se assemelham muito aos das escolas de samba. Apesar disso, existem combinações rítmicas, realizadas ao seu modo, que eu só ouvi, até o momento, nas La Ursas em São Caitano. Um deles era algo mais ou menos como mostra a seguinte figura (Fig. 14):

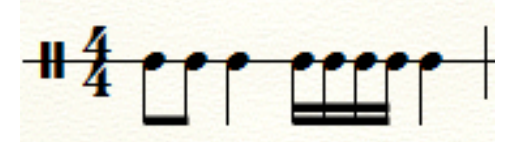

Fig. 14: Um dos ritmos realizado pelas La Ursas de São Caitano nos anos 1990. Fonte: Elaboração própria.

Somente esse pequeno trecho, descontextualizado de todos os elementos que compunham a música feita pelas La Ursas em São Caitano nos anos 1990, é muito pouco para mostrar tal particularidade musical. Entretanto, não tenho trechos maiores tão claros na memória que eu consiga transcrevê-los. Quando realizei a entrevista com Xoba, que afirma fazer até hoje a batucada tradicional, não foi possível realizar a demonstração rítmica, pois os instrumentos estavam guardados, e, por conta da pandemia, a entrevista aconteceu de maneira apressada, para evitar maior tempo de contato entre nós.

Baseados no desfile do concurso das La Ursas 2020 (CONCURSO DAS..., 2020), apresentamos a transcrição de dois trechos dos ritmos de duas La Ursas (Fig. 15 e 16). Devemos dizer que são partituras "hipotéticas", pois seria necessário um trabalho bem mais específico e com mais tempo para chegar a uma transcrição mais próxima do real. Na transcrição do Urso Rosas de Ouro (Fig. 16), é possível identificar combinações rítmicas que estavam presentes nas La Ursas dos anos de 1990, que passavam pelas ruas pedindo dinheiro de porta em porta. 


\section{URSO PANDA DA RUA 15 DE NOVEMBRO}

Carnaval das La Ursas de São Caitano 2020

Virada de entrada (Todos)
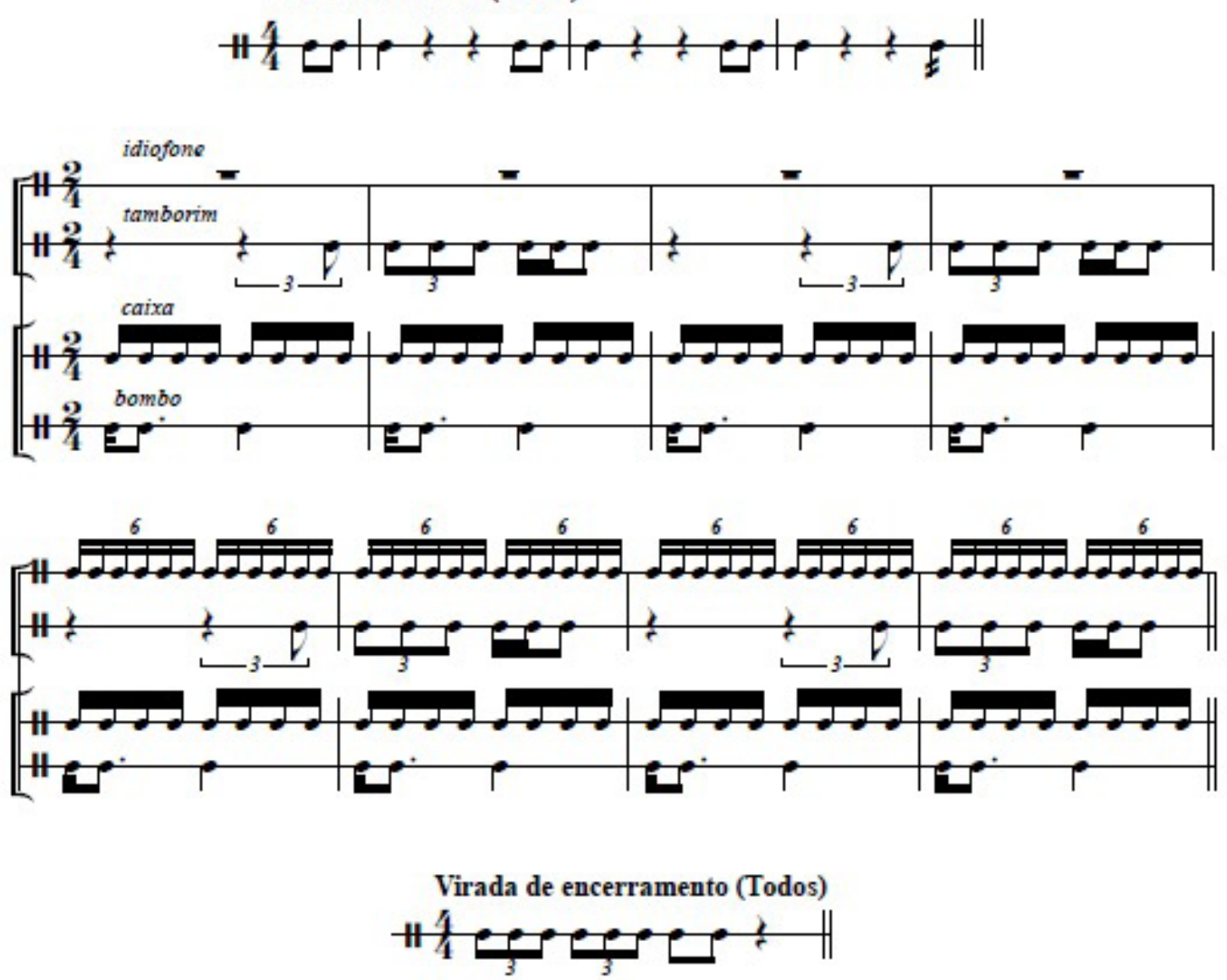

Fig. 15: Ritmo de parte das batidas do Urso Panda. Transcrição: Lucas Oliveira de Moura Arruda. 


\section{URSO ROSAS DE OURO}

Carnaval das La Ursas de São Caitano 2020

Transcrição: Lucas Oliveira de Moura Arruda
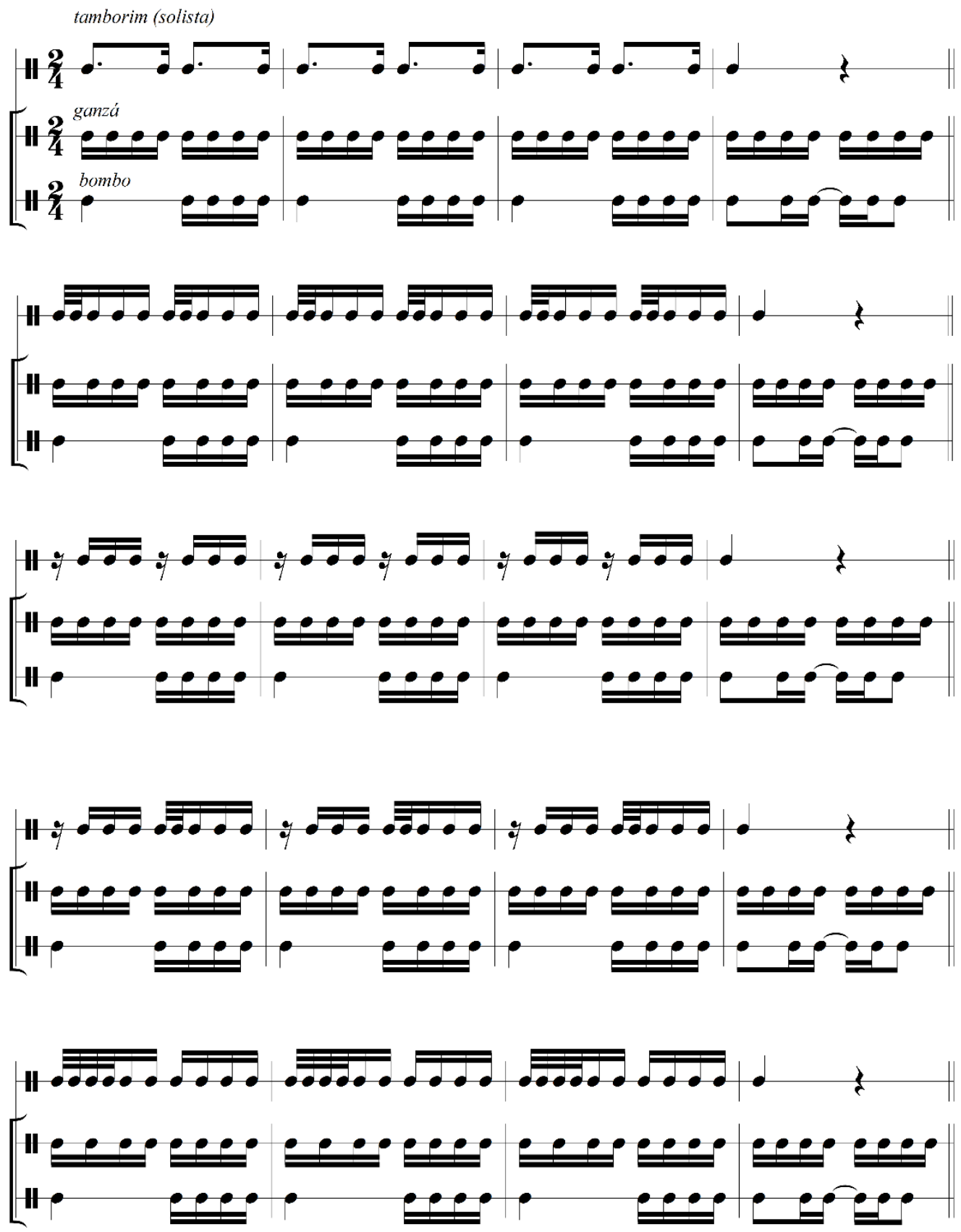

Fig. 16: Ritmo de parte das batidas do Urso Rosas de Ouro. Transcrição: Lucas Oliveira de Moura Arruda. 
No Urso Panda (Fig. 15), o idiofone faz um som como de um rufado. Ele aparece e depois some em meio à massa sonora. A timeline, feita pelo tamborim, se apresenta de certa forma defasada com relação ao bombo. A palavra "virada" é uma interpretação nossa (do etnomusicólogo que transcreveu). Pode ser que os músicos classifiquem com outro nome. Também não sabemos se chamam o bombo de zabumba e se existe um padrão de nomenclaturas entre os grupos. Xoba, por exemplo, chama os instrumentos ora pelos seus respectivos nomes, ora de batucada, quando estão juntos. Para uma outra pesquisa, seria interessante investigar a conceituação que cada grupo faz dos ritmos que executam. O tamborim tem papéis diferentes entre o Urso Panda (Fig. 15) e o Rosa de Ouro (Fig. 16). No primeiro tem uma função quase de timeline, uniforme. No segundo tem função quase melódica, de solista (observações também feitas por Lucas Oliveira de Moura Arruda).

Os grupos também se apresentam, no concurso, com temas. O Rosas de Ouro exibiu no último carnaval (2020) o tema "Piratas do Caribe", enquanto o Urso Panda compareceu com "Uma Fantástica Viagem ao Mundo Infantil". O Urso Leão Dourado, campeão de 2020, que homenageou Luiz Gonzaga, apresentou canções seguindo um enredo, o que é algo que passou a acontecer com o desfile das La Ursas em São Caitano. No entanto, o mais frequente atualmente ainda é a música somente instrumental. Também é possível identificar referências rítmicas de maracatus (culturas afro e negras). Talvez ao longo dos anos as La Ursas passem a homogeneizar esses elementos.

Não é possível, no entanto, a partir dos exemplos rítmicos que apresentamos, compreender, como um todo, como essa música (som) acontece. Pois as figuras musicais, baseadas numa escrita de uma outra cultura musical, dão indicação apenas de um aspecto. A produção da música, a diferença rítmica entre o que as La Ursas de São Caitano fazem em relação a outras manifestações culturais e musicais, também está relacionada com outras características, inclusive com os corpos dos instrumentistas e dos personagens, com a energia em torno do tocar, do desfilar, da competição do concurso.

A corporalidade enquanto fonte de energia coletiva que dá vida a formas sonoras é tematizada em um trabalho de pesquisa sobre os tambores do candombe uruguaio de Luis Ferreira (1997). Nesta música percussiva, produzida por dezenas de tambores, ocorre uma interação da energia própria do músico com a pressão do som coletivo e das vibrações do solo sobre o seu corpo. Vibrações fortes, quando originárias de uma fonte sonora, neste caso um grupo de candombe, mas também quando produzidas por uma bateria de escola de samba, e mesmo quando oriundas de caixas de som de um trio elétrico ou de uma discoteca, agem diretamente sobre o corpo humano. A partir de certo grau de intensidade, seja de volume ou seja por causa de uma excessiva duração temporal, a vibração rítmica tem tal impacto sobre o corpo, que pode levar a alteração de seu estado de consciência. (ROUGET, 1983 apud PINTO, 2001, n.p.).

Essa corporalidade aparece nos integrantes da troça como um todo. A La Ursa reflete isso em sua dança. Real fala que a dança da La Ursa durante o século XX era algo único de se ver no carnaval de Recife. O animal agarrava as pernas e fazia gestos que lembravam um urso de verdade (REAL, 1967, p.124). Xoba fala o seguinte sobre a dança 
do Urso: "Quando a gente tá ensaiando com a La Ursa, a gente deixa ele bem à vontade para ele gingar a dança dele" (XOBA, 2021).

Dando continuidade à citação apresentada por Tiago de Oliveira Pinto, o etnomusicólogo aponta que,

No caso do candombe uruguaio, a vibração coletiva não só toca os espectadores, como também "passa aos ombros e chega a braços e mãos" dos tamborileiros (FERREIRA, 1997, p.183). Produz-se assim, neste tipo de evento musical, uma constante reciprocidade de estímulos energéticos entre a corporalidade coletiva do todo (conjunto e audiência) e o corpo individual de cada músico em ação. (PINTO, 2001, n.p.).

Blacking explica que a música tem muito a ver com as experiências que as pessoas vivem em sociedade e com seus sentimentos. Ele enfatiza que ela "pode se tornar parte intrínseca do desenvolvimento da mente, do corpo e da harmonia nas relações sociais" (BLACKING, 2000, p.5). Na brincadeira da La Ursa, as pessoas não tocam sem motivo algum. Elas se envolvem, brincam, constituem a expressão. Com a criação do concurso, de uma competitividade entre os grupos, essa corporalidade tem parecido mais enfática. Sobre o que sente quando está tocando, Xoba coloca: "Eu fico emocionado. Até chorar eu já chorei muito no meio do carnaval. As lágrimas caindo e eu tocando". Ele explica que, quando está tocando, lembra da sua época de criança, e isso também o emociona (XOBA, 2021).

John Garçom (2020) esclarece que há muitos grupos de La Ursas em São Caitano e que eles movimentam uma espécie de carnaval nos bairros da cidade, mas que nem todos conseguem participar do concurso devido a questões financeiras, pois é necessário ter dinheiro para confeccionar roupas e outros elementos para o desfile. John Garçom ainda comenta que a prefeitura (gestão 2017-2020) tem ajudado com o valor de $\mathrm{R} \$ 1.000,00$ (mil reais) para cada grupo durante o carnaval. Ele diz que esse dinheiro ajuda, mas é muito pouco para o que as La Ursas da cidade merecem e necessitam para realizar o desfile.

John Garçom e Marliete falam que as pessoas que fazem parte dos grupos costumam pagar para fazer suas roupas. Os grupos também fazem eventos, rifas, vendem camisas dos seus respectivos Ursos (Fig. 17) para arrecadar fundos e investir na confecção de elementos para o desfile. No caso do Urso da Rua do Sapo (Fig. 18), por exemplo, são os integrantes que pagam o aluguel da sede e de outras coisas que necessitam (MARLIETE, 2021). 


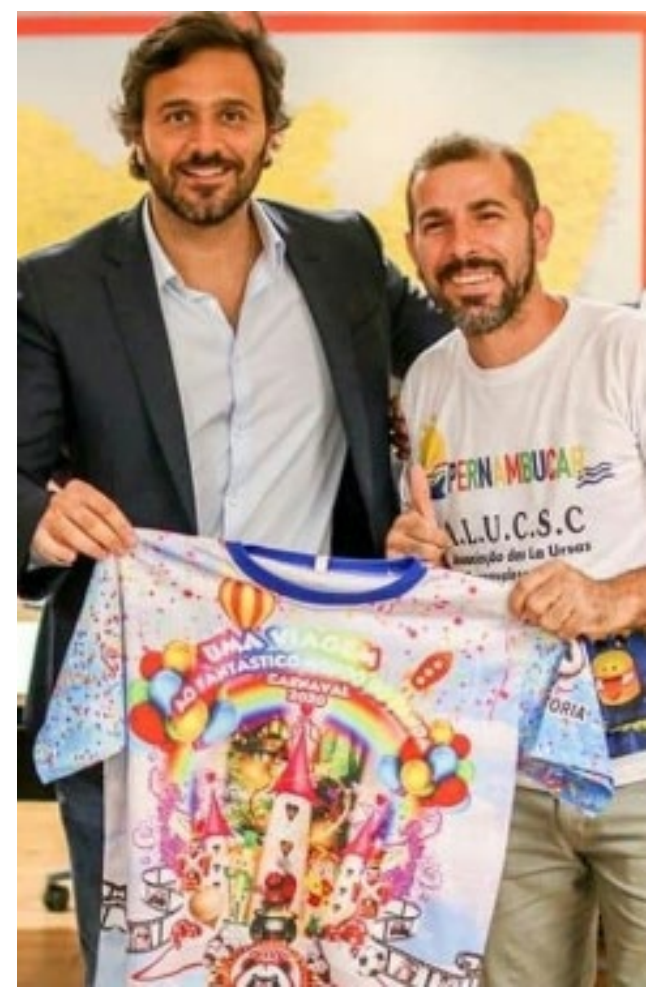

Fig. 17: Camisa do Urso Panda com o tema de 2020. Da esquerda para a direita: Rodrigo Novaes, secretário de Turismo de Pernambuco, e John Garçom, presidente da Associação das La Ursas de São Caitano. Fonte: (GRUPO CARNAVALESCO URSO PANDA, 2020)

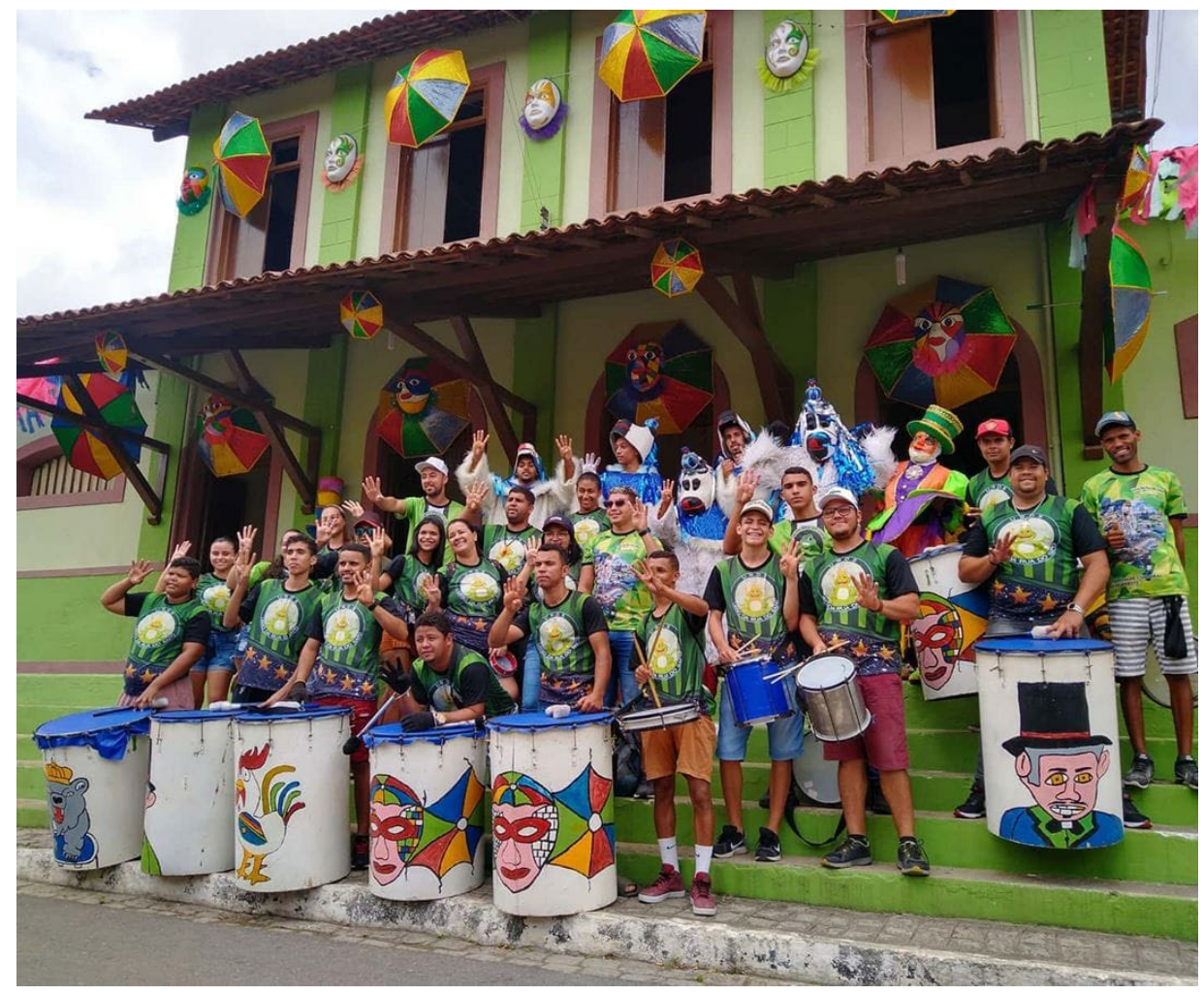

Fig. 18: Bateria do Urso da Rua do Sapo, na cidade de Bezerros (PE). Fonte: Fotografia enviada por Marliete. 
No último ano, 2020, participaram do desfile seis grupos de La Ursas: Urso Leão Dourado (1ำ lugar), Urso Nação Brasileira (2ำ lugar), ${ }^{22}$ Urso da Rua do Sapo (3ำ lugar), Urso Panda (4ำ lugar), Urso Cariri (5ำ lugar), Urso Rosas de Ouro (6ำlugar). O Urso Tô Nem Aí estava inscrito, mas não fez o desfile (LUIZ, 2020). É interessante destacar que o Urso Panda é o único com nome de urso mesmo. O local em que o desfile acontece é chamado de Ursódromo. O espaço que se transforma no Ursódromo é o que há ao lado da antiga estação ferroviária de São Caitano.

\section{Da cidade da raposa à cidade das La Ursas?}

Criar relações com as quais se identifique é algo presente na vida do ser humano há muito tempo. Contudo, na sociedade contemporânea ocidental, isso foi amplificado, sobretudo no século XX, com os nacionalismos, os regionalismos e as lutas de diferentes grupos (classe, gênero, etnia, entre outros). A necessidade de criar uma identidade é um meio de se destacar, a partir da diferença, dos demais grupos. Hall (2005) explica que na pós-modernidade grupos fixos começaram a se desintegrar e que outros surgiram. Como uma necessidade política e econômica, São Caitano encontrou nas La Ursas um meio de tentar desenvolver uma cadeia econômica baseada na cultura e no turismo.

No entanto, criar uma identidade no consciente social não é algo que acontece tão rapidamente. A cidade na qual está inserida a La Ursa que estamos abordando neste artigo é conhecida como "São Caetano da Raposa". Localizado no Vale do Ipojuca, o município, que tem uma estimativa de 37.119 habitantes, passou a ser chamado dessa forma quando se tornou distrito de Caruaru. Só perdeu o "da Raposa" em 1944, quando passou a ser grafado, inclusive, com "i” (IBGE, 2020).

Sobre a origem do "da Raposa", não há informações registradas. Porém, existe uma história que se conta na cidade, até mesmo nas escolas. De acordo com a professora Mariza Santos, a história diz que havia um poço de água na região. Os tangerinos, que levavam o gado do sertão para o litoral, usavam esse local como um dos pontos de parada para descansar e dar de beber aos animais. Um dia, quando um grupo deles chegou ao poço, havia uma raposa morta. Então passaram a chamar o lugar de "Poço da Raposa". Aos poucos o nome se estendeu para a localidade, que ficou conhecida como "São Caetano da Raposa" (MARIZA SANTOS, 2020). Essa relação com a "raposa" está tão intrínseca na população que a raposa é símbolo de muitas coisas na cidade. As La Ursas também utilizam essa imagem (Fig. 19).

22 Em 2020 a troça de Xoba compôs esse grupo de La Ursa. Ele levou dois Ursos de samambaia (XOBA, 2021). 


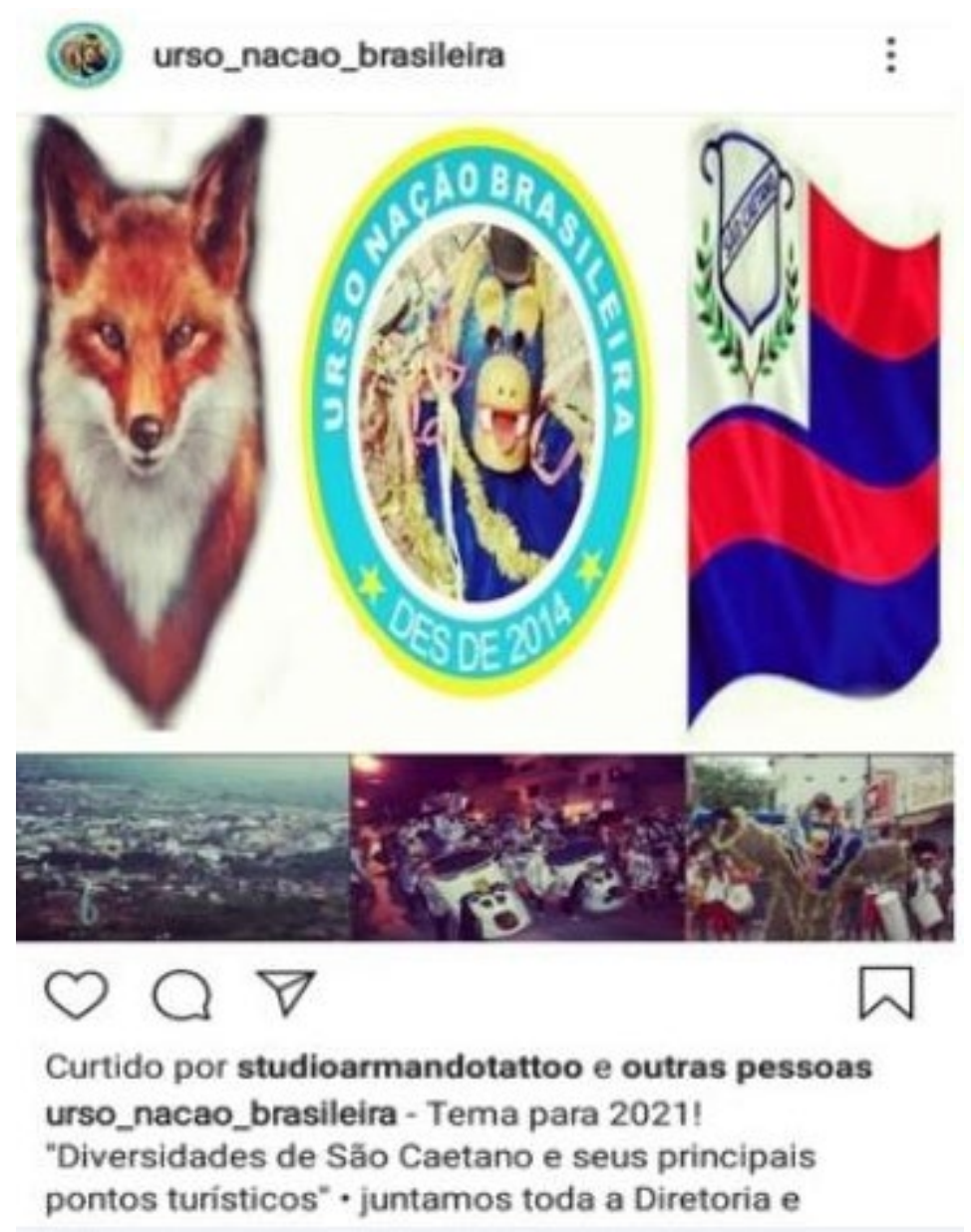

Fig. 19: Tema para 2021 do Urso Nação Brasileira. Quando lançaram, não havia como saber que em 2021 não haveria carnaval. Fonte: Urso Nação Brasileira (2020).

A identidade relacionada à raposa está tão presente em São Caitano que, embora moradores(as), e até mesmo o site da prefeitura, afirmem que existiu uma cultura da produção de café no lugar e que São Caitano já foi a cidade dos cafezais - com referências até mesmo no hino e na bandeira da cidade (MARIZA SANTOS, 2020; IBGE, 2020; SÃO CAETANO, 2020a) -, a maior parte da população nem tem conhecimento sobre isso. Da mesma forma, todas as pessoas com as quais conversamos e que não estão envolvidas diretamente com a brincadeira das La Ursas não sabem sobre a oficialização de São Caitano como a cidade das La Ursas. Acreditamos que isso acontece porque existem La Ursas em outras cidades.

Além disso, como já colocamos, não vimos nenhum trabalho de fortalecimento dessa identidade na cidade em 2020 nem nos primeiros quatro meses de 2021. Apesar do ano difícil, por conta da pandemia, os outdoors colocados em São Caitano não faziam nem fazem referência à brincadeira. Nenhuma placa foi feita, não há estátuas ou coisas que levem a população a enxergar São Caitano como a cidade das La Ursas. Durante a campanha eleitoral de 2020, nos debates que presenciamos, assim como nas campanhas dos candidatos, os poucos que falaram sobre as La Ursas pareciam não ter conhecimento sobre São Caitano já estar oficializada como a Cidade das La Ursas. Nem 
mesmo o prefeito (gestão de 2017-2020) chegou a colocar detalhes sobre algo que aconteceu em seu período como gestor.

O que notamos é que, para a criação de uma identidade local em São Caitano relacionada às La Ursas, há um emaranhado de várias relações de poder e de interesses, inclusive individuais.

Inseridos em um cenário onde as relações de produção e trocas orientam a vida social contemporânea, vivemos, constantemente, disputando espaço e reconhecimento. Essas competências quando alcançadas, permitem que tenhamos destaque em relação a outros, nos tornando distintos. No que diz respeito à cultura, de forma geral, essa perspectiva não é diferente e, de forma específica, se focarmos no tema brinquedos populares pernambucanos, dos quais fazem parte os maracatus, cavalos-marinhos, bumba-meu-boi, ursos, caboclinhos, entre outros, identificamos que a lógica mercantil, geralmente, os leva a buscarem essa distinção por meio de uma dinâmica de poder. (PEREIRA; BARBOSA, 2016, p.1).

Numa cidade como São Caitano, em que grande parte da população precisa se deslocar para outros lugares para trabalhar, aquilo que não gera renda acaba perdendo ou não ganhando espaço, que é o caso das La Ursas. A professora Mariza Santos (2020), que é funcionária pública efetiva na educação do município há mais de 33 anos, explica que nunca trabalhou as La Ursas em sala de aula, assim como não lembra de nenhum projeto sobre isso partindo da Secretaria de Educação da cidade ou das escolas nas quais lecionou. Ela explica que isso pode acontecer por falta de um material sobre as La Ursas, mas também acha que existe uma falta de interesse por parte das pessoas.

Xoba (2021) nos contou que se apresentou com sua troça várias vezes no Grupo Escolar Sizenando Leite de Macedo, escola da rede municipal de ensino de São Caitano que faz parte da sua comunidade. Mas, segundo ele, em nenhum momento o interesse partiu da gestão e demais funcionários. Era ele quem se oferecia para levar sua troça para comemorar a festa de carnaval com as crianças. Nesse sentido, era bem recebido pela equipe da escola. $O$ brincante também enfatiza que nunca chegou a falar sobre a La Ursa na escola (XOBA, 2021).

Pereira e Barbosa (2016, p.2) explicam que "há uma distinção entre os folguedos (brinquedos populares), ou seja, alguns se tornaram mais populares que outros, fenômeno que parece estar baseado nas relações de poder que são articuladas pelos diversos agentes que integram o mercado do entretenimento." Além disso, as questões culturais não são pensadas separadamente das econômicas.

Wacquant (2002) assume que o espaço social está organizado pelo imbricamento entre o capital cultural e econômico, onde constituem motivos de conflitos sociais. $O$ acúmulo desses capitais constitui os efeitos de uma dominação. $O$ objetivo nesse caso é se apropriar de uma identidade legítima e afirmá-la oficial e reconhecida. Para isso, é necessário enquadrá-la num mercado de bens simbólicos com regras e práticas próprias em busca de distinção. Entretanto, ao serem constituídos socialmente, estes bens devem ser modelados através de convenções sociais (MAUSS, 2002), para atender uma lógica de mercado, no caso, a Indústria Cultural. (PEREIRA; BARBOSA, 2016, p.7). 
A criação de uma associação, por exemplo, além de oficializar a existência das La Ursas em São Caitano, possibilita um reconhecimento que pode trazer apoios, inclusive financeiros. A iniciativa dos participantes do brinquedo de criar uma associação foi algo positivo para os grupos, mas notamos que pessoas que fazem parte dos grupos e das troças, que têm interesse real na brincadeira, não recebem ainda o destaque merecido.

Foram seis anos com uma associação não oficializada. Além disso, acreditamos que os grupos precisam se inteirar sobre os editais estaduais e nacionais voltados para as culturas populares para que possam competir com seus próprios projetos. O município também precisa começar a desenvolver medidas e eventos que tragam espaços para as culturas da terra e suas(seus) artistas. Como artista, que também sou, além de pesquisadora, posso garantir que, pelo menos nos últimos trinta anos, nenhuma gestão fez algo para valorizar de fato as(os) artistas de São Caitano,

A Associação das La Ursas também tem conta em redes sociais, nas quais posta eventos relacionados à brincadeira, mas necessita de uma assessoria de comunicação para a página ser apresentada com um aspecto mais profissional, que chame a atenção das pessoas, inclusive daquelas de fora de São Caitano. Isso seria importante também para as páginas individuais que muitos Ursos possuem. Nesse sentido, acreditamos que, havendo interesse da gestão da cidade, é possível: 1) desenvolver vários trabalhos que possam fortificar a imagem da La Ursa em São Caitano; 2) realizar cursos com as pessoas responsáveis pelos grupos, para que elas saibam administrá-los de uma forma mais eficiente, profissional e artística, inclusive por meio das mídias e redes sociais; 3) promover cursos para que os(as) integrantes dos grupos aprendam a fazer projetos culturais para que possam concorrer em editais estaduais e nacionais; 4) criar editais municipais que possam contemplar os(as) artistas e a cultura do lugar, como acontece em cidades como Recife, por exemplo.

Num depoimento pessoal, John Garçom (2020) nos contou que há máscaras que os grupos mandam fazer em outras cidades que custam mais de $\mathrm{R} \$ 500,00$ (quinhentos reais), o que é um custo bastante alto, considerando as condições financeiras das pessoas envolvidas na brincadeira. Xoba (2021) nos disse que há muitas pessoas em São Caitano que sabem fazer cabeças de La Ursas. Realizar oficinas em que os próprios integrantes pudessem ensinar outras pessoas também seria uma medida interessante a ser tomada pela gestão municipal. Além disso, promover cursos de aperfeiçoamento de confecção dessas máscaras, e outros acessórios que as La Ursas usam, poderia ser um meio de diminuir parte dos gastos que os grupos têm com os desfiles.

A realização de eventos diversos durante o ano também é algo que deve ser pensado. A inclusão do tema "La Ursa" nas escolas deveria ser um interesse das secretarias de Educação e de Cultura da cidade, assim como a discussão sobre as demais formas artísticas e expressões culturais que estão presentes no município, como as bandas de pífano, os bacamarteiros, os violeiros, os artistas da música popular e midiática, da música de concerto, os desenhistas, os pintores, os poetas e tantos(as) outros(as).

De acordo com Schechner (2011, p.29), as performances estão presentes nas produções artísticas e no cotidiano. O ato de nomear São Caitano a cidade das La Ursas já é uma performance que busca fixar essa "ideia" de identidade. Entretanto, essa relação 
identitária necessita estar no consciente social, como acontece com o "da Raposa". Não é o simples ato de nomear que vai tornar São Caitano a cidade das La Ursas. Se um dia as(os) cidadãs(ãos) da cidade se identificarão com as La Ursas, só saberemos a longo prazo.

\section{Considerações finais}

A La Ursa está presente em São Caitano há meio século, pelo menos. No carnaval, nas décadas de 1980 e 1990, os Ursos, junto com o "mela-mela", 23 eram as brincadeiras que tomavam conta de cidade. A La Ursa aparecia um mês antes do carnaval, animando as ruas com suas batucadas e gingas frenéticas. Depois dos anos de 1990, a brincadeira foi perdendo um pouco a força. Na última década, o interesse de brincar La Ursa foi sendo renovado, gerando várias transformações no brinquedo. Aos poucos as pessoas de diferentes classes sociais da cidade começaram a se identificar com a expressão. Apesar disso, o folguedo ainda se constitui como uma brincadeira de bairro e é composto por pessoas, em sua maior parte, de classes sociais mais baixas. A proposta do "novo" carnaval de São Caitano aborda a criação de uma identidade para a cidade, baseada na brincadeira das La Ursas.

Cada vez mais as brincadeiras e os folguedos precisam de um motivo oficial para existir. No caso das La Ursas de São Caitano, foi necessário criar um vínculo político e econômico, relacionando-as com a cultura. Os(As) próprios(as) brincantes carecem de objetivos para continuar fazendo a brincadeira. Nesse sentido, a La Ursa tem sofrido mudanças, seja na maneira de se apresentar, passando a competir, seja na adição de novos personagens, como as rainhas de bateria, uma quantidade maior de Ursos no mesmo grupo. A música (o som) nas La Ursas tem mostrado suas mudanças também. Notamos a presença de instrumentos de sopro, além dos já tradicionais instrumentos de percussão. Percebemos também a presença de um repertório com mais tipos (gêneros, estilos, ritmos) de músicas, algumas com letras (canções já conhecidas e enredos criados para o desfile, como fazem as escolas de samba). O grupo de instrumentistas forma o que a maior parte das La Ursas da cidade está chamando de bateria.

Devemos mencionar que os cargos que os interessados ocupam e a relação deles em promover o Carnaval das La Ursas em São Caitano com pessoas influentes politicamente é algo que está se mostrando eficiente e determinante nesse processo. Ou seja, é necessário haver um interesse dos poderes públicos para que essas expressões, como a La Ursa, continuem existindo. Sem um apoio da gestão da cidade, sem um trabalho de fortalecimento cultural, político e econômico em torno das La Ursas, o título da Cidade das La Ursas vai se perder antes mesmo de ser reconhecido pelo seu povo.

O que pode ser notado agora é que, dialogando com a questão da mobilidade das identidades colocada por Hall (2005), é possível dizer que está sendo criada uma fron-

23 É a brincadeira de sair sujando outras pessoas que se encontravam no meio da folia. Isso normalmente acontecia usando-se "trigo" (farinha de trigo), ovos ou carvão. Lembra o entrudo. "O entrudo era uma comemoração alegre, mas suja e violenta, que envolvia brincadeiras como andar pelas ruas e jogar água fria, farinha, barro, fuligem, goma, lixo e até urina nas pessoas. Depois as brincadeiras ficaram mais amenas e passou-se a usar laranjinhas-de-cheiro e borrachas com água perfumada. 0 entrudo era praticado por todos - inclusive escravos - nas várias regiões do país e perdurou entre nós até meados do século XIX, apesar das inúmeras tentativas das autoridades em proibi-lo" (ARANTES, 2013, p.8-9). 
teira identitária entre a Raposa e a La Ursa em São Caitano. Uma não tem que deixar de existir para a outra passar a atuar. Ainda segundo Hall, as identidades surgem e somem de acordo com diferentes situações, inclusive por meio da música. As batucadas das troças e baterias são essenciais para a transformação dos seres humanos em La Ursas de carnaval.

Com este artigo, esperamos contribuir para a difusão das La Ursas de São Caitano, da brincadeira de modo mais amplo, e para futuras pesquisas. Também queremos despertar nos órgãos de educação e cultura e nas(os) professoras(es) o interesse em trabalhar conteúdos relacionados às La Ursas nas escolas, o cuidado e a importância de salvaguardar nossa cultura.

Finalizamos o texto com uma fala de Xoba sobre a existência da La Ursa em São Caitano:

Enquanto eu tiver vivo, vai durar. Só se for autoridade empatar. ${ }^{24}$ Mas, enquanto não empatar... Olhe, enquanto eu tiver vivo, me arrastando, que eu tiver numa cadeira de roda, que Deus me livre e guarde, ainda que eu tiver na cadeira de roda, aí eu tô tocando. Pode levar eu numa cadeira de roda, pode botar um tarol que eu ainda toco. Se eu tiver com as duas mãos boas... (XOBA, 2021).

\section{Referências}

A LA URSA quer dinheiro: conheça. PE no Carnaval, 2019. Disponível em: https://www. penocarnaval.com.br/noticias/detalhe/a-la-ursa-quer-dinheiro-quem-nao-da-epirangueiro. Acesso em: 6 set. 2019.

ALCEU Valença - Como Dois Animais. [S. l.: s. n.], [ca. 2015]. 1 vídeo (4 min.). Publicado pelo canal Alfredo Pessoa. Disponível em: https://www.youtube.com/ watch?v=_1KvAdx4mUY. Acesso em: 12 abr. 2021.

ALVES, Igor. A la ursa, o urso do carnaval de pernambucano. História de Pernambuco - Carnaval. Empório Pernambucano, 20 jan. 2017. Disponível em: https://www. emporiopernambucano.com/single-post/2017/01/20/A-la-ursa-o-urso-do-carnavalPernambucano. Acesso em: 12 ago. 2018.

ARANHA, Camilo de Figueiredo. A brincadeira la ursa, visualidades e peripécias. Revista Digital do Laboratório de Artes Visuais, Santa Maria, ano 8, n. 4, p. 122-135, 2015.

ARANTES, Nélio. 2013. Pequena história do Carnaval no Brasil. Revista Portal de Divulgação, ano 3, v. 29, p. 6-20, 2013.

BACHMANN, Jennifer. A La ursa ganha as ruas do Recife Antigo com o bloco lírico O Bonde. João Alberto, 8 fev. 2019. Disponível em: http://www.joaoalberto.

24 Palavra que as pessoas usam com o significado de "impedir". 
com/2019/02/08/a-la-ursa-ganha-as-ruas-do-recife-antigo-com-o-bloco-lirico-obonde/. Acesso em: 5 maio 2019.

BENJAMIN, Roberto Emerson Câmara. Folguedos e danças de Pernambuco. Recife: Fundação de Cultura Cidade do Recife, 1989.

BLACKING, John. How musical is man? Seattle: University of Washington Press, 2000.

BLOCO DO URSO. Bloco do Urso 2020. Disponível em: http://www.blocodourso.com. br/. Acesso em: 5 set. 2020.

CONCURSO DAS La Ursas de São Caetano 2020. [S. l.: s. n.], 2020. 1 vídeo (228 min.). Publicado pelo canal Ativa Web TV. Disponível em: https://www.youtube.com/ watch?v=-I7RQQ9-s0E\&t=4728s. Acesso em: 13 mar. 2020.

CONCURSO DE La Ursas é realizado durante o carnaval, em São Caetano. G1, 7 fev. 2018. Disponível em: https://g1.globo.com/pe/caruaru-regiao/carnaval/2018/noticia/ concurso-de-la-ursas-e-realizado-durante-o-carnaval-em-sao-caetano.ghtml. Acesso em: 6 jun. 2020.

CUNHA, Ovídio da. Ursos e Maracatús. Contraponto, Recife, ano 2, n. 7, 1948.

ÊNIO QUIRINO (Ênio Gomes Quirino Menezes Leal). Entrevista concedida a Marília Santos em 23 maio 2020.

ESTEVES, Eduarda. Ainda existe La Ursa no seu bairro? Tradição luta para não desaparecer. Leia Já, 12 jan. 2018. Disponível em: http://carnaval.leiaja.ne10.uol.com. br/noticias/2018/01/12/ainda-existe-la-ursa-no-seu-bairro-tradicao-luta-para-naodesaparecer. Acesso em: 3 jun. 2020.

FUNDAÇÃO JOAQUIM NABUCO. Museu ensina crianças a fazer La Ursas e instrumentos para troça carnavalesca. Recife: Fundação Joaquim Nabuco, 2020.

Disponível em: https://www.fundaj.gov.br/index.php/area-de-imprensa/11741-museuensina-criancas-a-fazer-la-ursa-e-instrumentos-para-troca-carnavalesca. Acesso em: 11 fev. 2020.

GLEYBINHO (José Gleybson de Lima). Entrevista concedida a Marília Santos em 8 abr. 2021. WhatsApp.

GRUPO CARNAVALESCO URSO PANDA. 2020. agrupo_carnavalesco_urso_panda_. Instagram. Disponível em: https://www.instagram.com/grupo_carnavalesco_urso_ panda/. Acesso em: 12 abr. 2020. 
GRUPOS renovam tradição da La Ursa no carnaval de Pernambuco. NE1, 4 mar. 2019. Disponível em: https://globoplay.globo.com/v/7428825/. Acesso em: 4 mar. 2020.

HALL, Stuart. A identidade cultural na pós-modernidade. Rio de Janeiro: DP\&A, 2000.

IBGE. São Caitano. 2020. Disponível em: https://cidades.ibge.gov.br/brasil/pe/saocaitano/panorama. Acesso em: 4 jul. 2020.

JOHN GARÇOM (João Caetano de Assis). Entrevista concedida a Marília Santos em 16 jun. 2020. JOHN GARÇOM (João Caetano de Assis). Conversa informação com Marília Santos em 06 maio 2021.

\section{WhatsApp.}

LIMA, Cláudia M. de Assis Rocha. Ursos do Carnaval. Recife: Fundação Joaquim Nabuco, 2019. Disponível em: http://basilio.fundaj.gov.br/pesquisaescolar/ index.php?option=com_content\&view=article\&id=753\%3Aursos-docarnaval\&catid=55\%3Aletra-u\&ltemid=1. Acesso em: 5 set. 2019.

LUIZ, Adriano. La Ursas de São Caetano promoveram um espetáculo no carnaval. Blog do Adriano Luiz, 25 fev. 2020. Disponível em: http://www.blogdoadrianoluiz.com. br/2020/02/la-ursas-de-sao-caetano-promoveram-um.html. Acesso em: 6 jul. 2020.

MARIA DE LOURENÇO (Maria José Mendes Lima). Entrevista concedida a Marília Santos em 11 abr. 2021. Áudio.

MARIZA SANTOS (Mariza Simplício dos Santos). Entrevista concedida a Marília Santos em 11 ago. 2020. Áudio.

MARLIETE (Marliete Joaquim da Silva). Entrevista concedida a Marília Santos em 11 abr. 2021. WhatsApp.

MARTINS, Magno. Carnaval 2020: Prefeitura do Ipojuca anuncia tema e homenageado. Blog Magno Martins com Ítala Alves, 11 jan. 2020. Disponível em: https://www. blogdomagno.com.br/ver_post.php?id=208859\&pagina=10227. Acesso em: 5 abr. 2020.

MARTINS, Paulo Henrique. A sociologia de Marcel Mauss: dádiva, simbolismo e associação. Revista Crítica de Ciências Sociais, n. 73, p. 45-66, 2005. 
NEPOMUCENO, Cristiane Maria. O jeito nordestino de ser globalizado. 193 f. Tese (Doutorado) - Centro de Ciências Humanas, Letras e Artes, Programa de PósGraduação em Ciências Sociais, Natal, 2005.

O BONDE lírico desfilará homenageando a La Ursa no Recife Antigo. Diário de Pernambuco, 29 jan. 2020. Disponível em: https://www.diariodepernambuco.com.br/ noticia/viver/2020/01/homenageando-a-la-ursa-o-bonde-lirico-desfila-nas-ruas-dorecife-anti.html. Acesso em: 3 jun. 2020.

PEREIRA, Roberta de Albuquerque; BARBOSA, Maria de Lourdes de Azevedo. Brinquedos do carnaval pernambucano: um "campo de lutas" cultural entre Maracatu Rural e Ursos baseados na construção social bourdiesiana. In: SEMINÁRIO DA ANPTUR, 13., 2016, São Paulo. Anais [...]. São Paulo, 2016. p. 1-14.

PERNAMBUCO. Secretaria de Cultura. Carnaval 2020: convocatória do ciclo carnavalesco. Bora Pernambucar no Carnaval encerra programação com homenagem ao Dia do Frevo. Recife: Cultura.PE, 2020. Disponível em: http://www.cultura.pe.gov. $\mathrm{br} / \mathrm{canal} / \mathrm{carnaval} /$ bora-pernambucar-no-carnaval-encerra-programacao-comhomenagem-ao-dia-do-frevo/. Acesso em: 6 jul. 2020.

PESSOA, Breno. Prévias carnavalescas no bairro do Recife atraem foliões. Diário de Pernambuco, 21 jan. 2018. Disponível em: https://www.diariodepernambuco.com. $\mathrm{br} /$ noticia/vidaurbana/2018/01/previas-carnavalescas-no-bairro-do-recife-atraemfolioes.html. Acesso em: 26 mar. 2018.

PINTO, Tiago de Oliveira. Som e Música. Questões de uma Antropologia Sonora. Revista Antropologia, ano 1, v, 44, 2001. Disponível em: scielo.br/scielo. php? script=sci_arttext\&pid=S0034-77012001000100007\&lng=pt\&nrm=iso\&tlng=pt. Acesso: 5 jul. 2020.

REAL, Katarina. A "La Ursa" - os ursos de carnaval do Recife. In: REAL, Katarina. 1967. O folclore no carnaval do Recife. Rio de Janeiro: Ministério da Educação e Cultura (Campanha de Defesa do Folclore Brasileiro), 1967. p. 122-130.

REINAUX, PH. Bora Pernambucar no Carnaval 2020. Publicado por Fundarpe. Recife, 8 fev. 2020. 1 fotografia. Disponível em: https://www.flickr.com/photos/ fundarpe/49511661816/in/photostream/. Acesso em: 13 ago. 2020.

RENATA, Léa. Carnaval da La Ursa em São Caetano. Blog do Wagner Gil, 7 fev. 2018. Disponível em: https://blogdowagnergil.com.br/vs1/2018/02/07/carnaval-da-la-ursaem-sao-caetano/. Acesso em: 6 jun. 2020. 
RODRIGO NOVAES (Rodrigo Cavalcanti Novaes). Entrevista concedida a Marília Santos em 26 jul. 2020. WhatsApp.

SÃO CAETANO. Município de São Caetano. São Caetano: Prefeitura de São Caetano, 2020a. Disponível em: https://saocaetano.pe.gov.br/historia/. Acesso em: 4 jun. 2020.

SÃO CAETANO. São Caetano mantém a cultura com o carnaval das "La Ursas". São Caetano: Prefeitura de São Caetano, 2020b. Disponível em: https://saocaetano.pe.gov. $\mathrm{br} /$ ? portfolio=sao-caetano-mantem-a-cultura-com-o-carnaval-das-la-ursas. Acesso em: 6 jun. 2020.

SCHECHNER, Richard. Performers e espectadores: transportados e transformados. Trad. Selma Treviño. Moringa, ano 2, v. 1, p. 155-185, 2011.

GAIA, Sérgio. @asergiogaiaoficial. Instagram. 2021. Disponível em: https://www. instagram.com/sergiogaiaoficial/. Acesso em: 14 abr. 2021.

SILVA, Luiz. Bloco do Zé Pereira abre a programação de shows no carnaval das La Ursas em São Caetano. Blog Jardim do Agreste, 23 fev. 2020. Disponível em: https:// jardimdoagreste.com.br/bloco-do-ze-pereira-abre-a-programacao-de-shows-nocarnaval-das-la-ursas-em-sao-caetano/. Acesso em: 26 mar. 2020.

URSO NAÇÃO BRASILEIRA. @urso_nacao_brasileira. Instagram. 2020. Disponível em: https://www.instagram.com/urso_nacao_brasileira/. Acesso em: 11 abr. 2020.

URSOS (La Ursa). Carnaval Recife, 2020. Disponível em: http://site.carnavalrecife.com/ compositores-e-agremiacoes/ursos-la-ursa/. Acesso em: 5 maio 2020.

XOBA (Luiz Antônio Henrique dos Santos). Entrevista concedida a Marília Santos em 10 abr. 2021. Áudio. 